\title{
Article \\ The Air Quality Impact Evaluation of Modular Construction Practices in Hong Kong and Singapore
}

\author{
Riqi Zhang ${ }^{1,2,3}$ and Yishuang $\mathrm{Xu}^{4, *}$ \\ 1 School of GeoSciences, University of Edinburgh, Edinburgh EH8 9XP, UK; riqi.zhang@icloud.com \\ 2 Scotland's Rural College (SRUC), Edinburgh EH9 3JG, UK \\ 3 Centre for Environmental Policy, Faculty of Natural Sciences, Imperial College London, London SW7 1NE, UK \\ 4 Manchester Urban Institute, School of Environment Education and Development, University of Manchester, \\ Manchester M13 9PL, UK \\ * Correspondence: yishuang.xu@manchester.ac.uk; Tel.: +44-016-1275-8688
}

check for updates

Citation: Zhang, R.; Xu, Y. The Air Quality Impact Evaluation of Modular Construction Practices in Hong Kong and Singapore. Sustainability 2022, 14, 1016. https://doi.org/10.3390/su14021016

Academic Editor:

Elena Cristina Rada

Received: 18 November 2021

Accepted: 31 December 2021

Published: 17 January 2022

Publisher's Note: MDPI stays neutral with regard to jurisdictional claims in published maps and institutional affiliations.

Copyright: () 2022 by the authors Licensee MDPI, Basel, Switzerland. This article is an open access article distributed under the terms and conditions of the Creative Commons Attribution (CC BY) license (https:// creativecommons.org/licenses/by/ $4.0 /)$.

\begin{abstract}
As a new approach to construction practice, modular construction allows the building to be split into modular units and prefabricates them in factories, transports the units to the site, and assembles them into the whole construction through reliable connections. Whilst it is regarded to be the future direction in the development of the construction industry, Hong Kong and Singapore, amongst many other cities, both use modular constructions in public and private constructions. There have been many evaluations of the sustainability performance of a single construction using modular constructions, but the environmental impacts of implementing modular constructions on a city scale have been rarely explored. Few scholars have studied the impact of the application of this technology on the air quality on a small regional scale. Therefore, this study aims to fill this gap by comparing and analysing the modular construction policies in Hong Kong and Singapore and evaluating the impact of the policies on air quality in the two cities. By using OLS and DID analysis, we found that the air quality can be affected by modular construction, though the impact was found to be limited. The modular construction policies had a positive effect on sulphur dioxide $\left(\mathrm{SO}_{2}\right)$ emissions in both cities, and a negative effect on nitrogen dioxide $\left(\mathrm{NO}_{2}\right)$ and particulate matter $<10 \mu \mathrm{m}\left(\mathrm{PM}_{10}\right)$ emissions. Meanwhile, greenhouse gases $(\mathrm{GHG})$ and ozone $\left(\mathrm{O}_{3}\right)$ varied between the two.
\end{abstract}

Keywords: modular construction; policy impact; air quality impact evaluation; difference-in-difference (DID)

\section{Introduction}

Since the 1990s, the industrial sector including the construction sector has begun to pay attention to the environmental impact of its activities, and reforms are needed to reduce the environmental impact of the construction sector [1]. The design, construction, and operation of buildings need to be improved to reduce the pressure on the environment. Construction companies must conduct pre-analysis to measure the possible environmental impacts of their products and activities and try to find solutions to minimize these impacts [2]. Modular construction is one of the solutions for the construction sector to reduce its negative environmental impact because it is more environmentally friendly than traditional construction methods and can reduce the negative impact on air quality to a certain extent $[3,4]$.

In the past two decades, Hong Kong and Singapore have both issued relevant policies on modular construction practices to promote the application of modular construction technology in the public and private sectors [5]. Although modular construction technology has been rapidly applied in the construction practice of the two cities, there are differences in time and design standards in the issuance of policies and regulations on modular constructions in these two cities. The sustainability performance is also very different, namely, the application of modular constructions has different effects on the air quality of the two cities. Many have evaluated the sustainability of a single construction project using modular construction technology, but the environmental consequences of implementing 
modular constructions on a city scale have been rarely explored [4,6,7]. Many studies have focused on how the modular construction technology can be improved as well as how the modular construction system is designed [8-10]. Few scholars have studied the impact of the application of this technology on the regional air quality. This study aims to fill this gap. The changes to the air quality were investigated via five gas emissions data to learn how the technology helps to improve the environment. To be more specific, this study focused on exploring the impact of modular construction on the ecological environment of Hong Kong and Singapore such as the reduction in GHGs and air pollutant emissions.

In this study, the core content and implementation time of the modular construction policy in Hong Kong and Singapore were reviewed and the main driving factors for the development of modular construction technology identified. The impact of modular construction policies on the emissions of the major five gases (GHG, $\mathrm{NO}_{2}, \mathrm{O}_{3}, \mathrm{PM}_{10}$, and $\mathrm{SO}_{2}$ ) in Hong Kong and Singapore were analysed by both the OLS and DID method. Our findings show that the modular construction policy has a positive effect on GHG emissions in both cities, and a negative effect on nitrogen dioxide $\left(\mathrm{NO}_{2}\right)$ emissions. Meanwhile, ozone $\left(\mathrm{O}_{3}\right)$, particulate matter $<10 \mu \mathrm{m}\left(\mathrm{PM}_{10}\right)$, and sulphur dioxide $\left(\mathrm{SO}_{2}\right)$ varied between them. This implies that the air quality can be affected by modular construction practice though the impact depends on how widely the model is used.

\section{Literature Review}

\subsection{The Effects of Modular Construction}

In order to improve the understanding of modular constructions, some studies have been devoted to quantitatively evaluating the performance of modular constructions and comparing them with traditional constructions. These studies mainly compare the impact of architecture on the three key dimensions of sustainability (economic, environmental, and social) [11]. Kamali and Hewage [12] established sustainable development assessment indicators including economic indicators, social indicators, and environmental indicators. Hammad et al. [13] compared modular and traditional constructions by quantifying economic, environmental, and social factors through decision support tools of building information modelling (BIM).

Economic performance is one of the key concerns of construction professionals [14]. Studies generally believe that the cost of modular construction is lower than that of traditional construction [15-17]. However, some studies have found that the cost of modular constructions is higher than that of traditional constructions. The increase in cost is mainly reflected in the production and transportation of precast concrete (PC) construction [18]. Luo and Li [19] found that with the increase in prefabrication rate, the cost of modular constructions increased first and then decreased. The research by Zhang et al. [20] showed that prefabricated parts have been widely used in public housing projects in Hong Kong, which developers in the private sector are still hesitant to use. This can be explained by the high transport cost (13-17\% higher) of the prefabricated building modules that are delivered from mainland China [21]. Liew [22] found that the unit cost of modular constructions was lower than traditional constructions mainly due to the fact that Singapore's mature modular construction technology reduces manufacturing costs.

Although the economic benefits of modular constructions are different in different regions due to technical and transportation reasons, in terms of the environment, modular constructions have a very good performance. Modular constructions can effectively reduce energy consumption, construction waste emissions, and GHG emissions [23-26]. Quale [7] pointed out that the impact of modular constructions on the environment was less than that of traditional constructions, but that the gap between specific projects was different. A case study in Hong Kong showed that compared to traditional constructions, modular constructions saved 224 tons of wood and reduced construction waste emissions by 69\% [27], while GHG emissions from high-rise private residences in Hong Kong using prefabricated components could be reduced by $10 \%$ [24]. A case in Singapore confirmed that when using modular construction methods, the construction waste of the project could be reduced by $70 \%$ [28]. 
The social performance evaluation of modular constructions focuses on its impact on the workers' health, safety and working hours, users of buildings, communities, and society [20]. Liu and Qian [11] pointed out that the social sustainability of modular constructions was better than traditional constructions. Modular constructions have obvious advantages for workers' health, safety, and working hours, but for other indicators such as users' evaluation of building comfort and the noise impact on the community, these are not significantly different from traditional construction methods. Despite the different types of projects, modular construction has been proven to be a health insurance for workers and a reduction in working hours in many cases. Hammad [13] pointed out that modular constructions could shorten the construction period by about $40 \%$ compared to traditional constructions. According to Rahman and Sobuz [28], in the case of modular constructions in Singapore, the construction period could be shortened by $2-6$ months. The modular construction also simplifies the construction process and reduces the health and safety risks of the workers by avoiding additional operations such as avoiding the construction of scaffolding to eliminate the risk of falling from high altitude [22]. In addition, modular construction also reduces disputes between the construction party and the community during construction (e.g., occupation of roads), which helps the construction party and the community to live in harmony [27].

\subsection{Modular Construction's Impact on Air Quality}

Compared with traditional construction methods, modular construction can significantly reduce the negative impact on air quality. These effects are mainly reflected in the reduction in GHGs (mainly $\left.\mathrm{CO}_{2}\right)$, nitric oxide metabolite $\left(\mathrm{NO}_{\mathrm{X}}\right)$, and particulate matter (i.e., particulate matter $<2.5 \mu \mathrm{m}\left(\mathrm{PM}_{2.5}\right)$ and particulate matter $\left.<10 \mu \mathrm{m}\left(\mathrm{PM}_{10}\right)\right)$ emissions, thereby effectively improving the environment around the building $[3,4,7,29]$.

Buildings are one of the main sources of GHGs, and $\mathrm{CO}_{2}$ is the most important GHG [30]. Buildings actually produce GHG emissions at all stages of their entire life cycle. With the traditional methods, approximately $60 \%$ of GHGs were emitted during the construction phase [7]. Modular constructions can reduce on-site construction during the entire life cycle of the building, thereby improving construction efficiency and reducing GHG emissions [30]. However, the extent to which GHG emissions can be reduced through modular constructions varies. In concrete buildings, Kawecki [31] found that the use of modular construction methods will result in higher GHG emissions of houses than traditional construction methods. However, the research by Pons and Wadel [32] research showed that the use of modular constructions in concrete buildings will reduce GHG emissions. The use of modular constructions can reduce $\mathrm{CO}_{2}$ emissions by $30 \%$ compared to traditional construction methods [7]. In wooden buildings, Al-Hussein et al. [33] found that the use of modular construction methods in low-rise wooden buildings could reduce $\mathrm{CO}_{2}$ emissions by $43 \%$. However, in mid-rise wooden buildings, the use of modular construction methods can only reduce $12.6 \%$ of carbon dioxide emissions [34]. Due to the differences in a series of variables such as building location, building type, and structural materials, it will inevitably lead to huge differences in the results of comparing the GHG produced by the two methods [35].

$\mathrm{NO}_{X}$ and particulate matter (i.e., $\mathrm{PM}_{2.5}$ and $\mathrm{PM}_{10}$ ) caused by construction activities are important sources of air pollution [29]. NOX mainly comes from vehicle exhaust emissions and industrial exhaust emissions, but it also emits a small amount during building construction [36]. The $\mathrm{NO}_{X}$ in traditional constructions mainly comes from the energy consumption at the construction site (e.g., use diesel generators), while the modular construction reduces the amount of construction tasks at the construction site and thus reduces the energy consumption, which can reduce $\mathrm{NO}_{X}$ emissions by about $13 \%$ [7]. Construction dust caused by construction activities is the main source of particulate pollution and contributes significantly to $\mathrm{PM}_{2.5}$ and $\mathrm{PM}_{10}$ in the atmospheric environment, up to $70 \%$ [37]. Construction dust refers to dust caused by construction activities such as construction and demolition [38]. Dust is generated by human activities at the construction 
site and becomes particles (mainly $\mathrm{PM}_{2.5}$ and $\mathrm{PM}_{10}$ ) as the air flows [39]. The activities of construction workers or the operation of machines will generate large amounts of dust suspended in the air, thereby reducing air quality [40]. In the traditional construction method, the construction dust in the foundation excavation, backfilling, and construction phase is more serious, mainly from earthwork construction and on-site mixing of cement mortar [29]. The modular construction method can reduce on-site building construction (e.g., reduce cement mixing and steel processing at the construction site) to reduce dust emissions, and can reduce $\mathrm{PM}_{2.5}$ and $\mathrm{PM}_{10}$ emissions by about $30-60 \%$ depending on the project scale [39,41,42]. Lawson et al. [42] found in a case study in England where modular constructions reduced particulate emissions by $30-50 \%$ compared to traditional constructions.

\subsection{Factors Affecting Air Quality}

Several factors have been found to affect the air quality in Hong Kong and Singapore $[43,44]$ and can be categorised as: (1) Natural factors such as season, rainfall, sunshine time, lightning, wind speed, and terrain factors (which have certain effects on air pollution) [45]; and (2) Socio-economic factors such as social production and economic activities in various regions, which have impacts on regional air quality [44]. The World Health Organisation [46] identified several socio-economic factors that have a major influence on air pollution. Most of them (i.e., population, economic scale, industrial structure, energy consumption, number of motor vehicles, number of ships, urbanisation rate) have been investigated and found to affect the air quality in Hong Kong and Singapore [43,44]. Table 1 presents the summary of these factors. Moreover, socio-economic development and environmental protection are interdependent and mutually restrictive, which need to be balanced to achieve the goal of sustainable development [12].

Table 1. The socio-economic factors influencing air pollution in Hong Kong and Singapore.

\begin{tabular}{ccccc}
\hline Index & Factor & Hong Kong & Singapore & Sub-Category \\
\hline 1 & Population & $\sqrt{ }$ & $\sqrt{ }$ & Demographic factors \\
2 & GDP & $\sqrt{ }$ & $\sqrt{ }$ & Economic scale \\
3 & GDP growth rate & $\sqrt{ }$ & $\sqrt{ }$ & \\
4 & GDP per capita & $\sqrt{ }$ & $\sqrt{ }$ & Scale and proportion of secondary industry \\
5 & Industrial output & $\sqrt{ }$ & $\sqrt{ }$ & Energy consumption \\
6 & Proportion of secondary industry & $\sqrt{ }$ & $\sqrt{ }$ & Motor vehicle exhaust \\
7 & Total energy consumption & $\sqrt{ }$ & $\sqrt{ }$ & Ship exhaust \\
8 & Total power consumption & $\sqrt{ }$ & $\sqrt{ }$ & Urbanisation \\
9 & Number of motor vehicles & $\sqrt{ }$ & $\sqrt{ }$ & Environmental policy \\
10 & Number of ships & $\sqrt{ }$ & $\sqrt{ }$ & $\sqrt{ }$ \\
11 & The ratio of urban built-up area to & $\sqrt{ }$ & $\sqrt{ }$ & \\
12 & Environmental governance funds & $\sqrt{ }$ & &
\end{tabular}

3. Background-The Development of Modular Construction in Hong Kong and Singapore

\subsection{Development of Modular Construction in Hong Kong}

Since the late 1980s, due to the implementation of standardised house design, in order to speed up construction, ensure construction quality, and achieve environmental protection, the Hong Kong Housing Authority and Housing Department proposed the concept of prefabricated components and began to use prefabricated concrete components [20,47]. After the success of external wall prefabrication, the Hong Kong Housing Authority and Housing Department further promoted the prefabricated industrial construction method. At present, the highest prefabricated ratio that has been reached is $40 \%$ (e.g., Kai Tak $1 \mathrm{~A}$ project) [48].

The standardisation of the design of public houses makes it possible to produce prefabricated components on a large scale, which leads to good efficiency and benefits. After 1998, private housing development projects also began to apply prefabricated exterior wall technology. However, due to the high cost of prefabricated exterior walls, before 
2002, only four private housing projects in Hong Kong adopted this technology [47,48]. Its extensive use began in 2002, which is mainly attributed to two government policies. In order to encourage developers to provide environmentally friendly facilities, adopt environmentally friendly building methods and technological innovation, the Building Department issued "Joint Practice Note No. 1" and "Joint Practice Note No. 2" in 2001 and 2002. The introduction of the policy at each stage is provided in Appendix A. Projects stipulated using prefabricated components such as non-structural exterior walls, sky gardens, and terraces were exempted from the area. At present, most private houses use prefabricated exterior walls [48].

\subsection{Development of Modular Construction in Hong Kong}

In Singapore in the 1970s, prefabricated engineering techniques were only used on prefabricated pipe culverts and prefabricated bridge components. It was not until the early 1980s that the Singapore Housing and Development Board (HDB) began to gradually introduce the concept of prefabricated construction into residential projects and stated it to be the industrialisation of construction [49].

Due to the shortage in both domestic and foreign workers in Singapore, the Building and Construction Authority of Singapore (BCA) proposed and compiled the Buildable Design Appraisal System (BDAS) as early as 1992 to rate the buildability of buildings [50]. The system is intended to start from the design stage, the source of engineering construction, to reduce the number of workers on the construction site, improve construction efficiency, and improve construction methods as a guiding direction to develop a scoring system. In the Code of Practice on Buildable Design promulgated by the Building and Construction Authority in 2000, the minimum buildable score was first proposed. If the submitted buildability score is lower than the minimum required score, it will not be approved. Prefabricated components are formally incorporated into this code of practice, and the use of prefabricated components can improve building constructability scores [51]. Appendix B lists the relevant policies, regulations, and codes in Singapore.

Singapore's HDB housing system began in the 1960s [52]. At that time, Singapore had just separated from British colonial rule and established an autonomous organisation. The development of the whole society was relatively backward. The government's financial resources were limited, and the housing conditions of the people were relatively poor. The slogan Lee Kuan Yew put forward at the time was to realise Singaporean "Home Ownership for the People Scheme". Since then, the Singapore government has taken the housing problem as a basic national policy and established the HDB in 1960. The occupancy rate of HDB flats in the country reached its peak in the 1990s. Early HDB houses were mostly six to 10 stories high, and newly built HDBs are mostly 13 to 17 stories high. The assembly rate of newly built HDBs has reached over $70 \%$, and the prefabricated rate of some HDBs has reached over $90 \%$ (e.g., the Pinnacle@Duxton project, where the prefabricated rate reached 94\%) [53].

\section{Methodology}

\subsection{Research Design}

As in the empirical investigation, the ordinary least square (OLS) regression was used in each city while the difference-in-difference (DID) method was adopted to explore the impact in a more accurate context with two groups (cities) in the empirical investigation.

This study used the DID model to analyse the impact of modular construction policies on air quality and regarded the promotion of the use of modular construction as a natural experiment to examine the changes in local air quality by implementing modular construction in Hong Kong and Singapore. Cities where modular construction policies were implemented were defined as experimental groups, and cities where modular construction policies were not implemented were defined as control groups. We constructed the dummy variables $M_{i t}, M_{i t}=1$ to indicate that city $i$ is the city where the modular construction policy is implemented, and is the experimental group. $M_{i t}=0$ indicates that city $i$ is a city where the modular construction policy has not been implemented, and it is a control 
group. Simultaneously, we constructed the dummy variable Time $_{i t}$. Time $e_{i t}=0$ means before policy implementation, Time $_{i t}=1$ means after policy implementation. $Z_{s t}$ is another factor (non-policy factor) that affects regional air quality including industrial power consumption, number of motor vehicles, number of ships, etc. Therefore, a regression model as shown in Equation (1) is the basis of the empirical investigation.

$$
y_{i t}=a_{0}+a_{1} M_{i t}+a_{2} \text { Time }_{i t}+a_{3} M_{i t} * \text { Time }_{i t}+a_{4} Z_{i t}+\varepsilon_{i t}
$$

where $i$ and $t$ refer to the city and time (in years); $M_{i t} *$ Time $i t$ is the cross term, the comprehensive variable of the policy implementation city and time; and $\varepsilon_{i t}$ is the error term. The coefficient $a_{3}$ of this dummy variable was the focus of this study and measures the impact of the implementation of the modular construction policy on the explained variable $y$, that is, the air quality of the city.

\subsection{Data Description}

\subsubsection{Data Source}

This study collected data based on the time points of the modular construction policies published by the government in Hong Kong and Singapore (Appendices A and B), and selected data from Hong Kong and Singapore from 1998 to 2004 to investigate the impact of the government's implementation of modular construction policies on air quality. In order to compare the air quality of the two places before and after the implementation of the policy, it is necessary to choose the period of comparison between the regions. Since the sovereignty of Hong Kong was transferred from the United Kingdom to mainland China in July 1997, a large number of companies were evacuated from Hong Kong, and the economic situation of Hong Kong has changed significantly [54]. In order to avoid changes in air quality caused by economic fluctuations due to the transfer of sovereignty, the year of 1998 was selected as the starting time of Hong Kong's data, that is, two years before 2000 (the time when Singapore's modular construction policy was announced). The time comparison selection takes five years as a phase, comparing Singapore (experimental group) and Hong Kong (control group) from 1998 to 2002 and comparing Hong Kong (experimental group) and Singapore (control group) from 2000 to 2004 to study the impact of the modular construction policies on air quality. In the selection of the comparison group, considering the geographical location, climate, and political system, Hong Kong and Singapore were selected for comparison. Therefore, the relevant data of Hong Kong and Singapore from 1998 to 2004 were collected. The sources of economic data and air quality data for the two locations include: the World Bank, Hong Kong Census and Statistics Department, Marine Department, Transport Department and Environmental Protection Department, Department of Singapore Statistics, and the National Environment Agency. The air quality data include the annual mean of $\mathrm{NO}_{2}$, maximum 8-hour mean value of $\mathrm{O}_{3}$, annual mean of $\mathrm{PM}_{10}$, and annual mean of $\mathrm{SO}_{2}$.

\subsubsection{Selection and Interpretation of Variables}

This study built a DID model on the impact of modular construction policies on the air quality of Hong Kong and Singapore, thus indicator(s) that can reflect the air quality are key. Important indicators for evaluating air pollution are black carbon, carbonic oxide (CO), $\mathrm{NO}_{2}, \mathrm{O}_{3}, \mathrm{PM}$, and $\mathrm{SO}_{2}$ [46]. Due to the availability of data, $\mathrm{NO}_{2}, \mathrm{O}_{3}, \mathrm{PM}_{10}$, and $\mathrm{SO}_{2}$ were selected. Pollutants were used as indicators (dependent variables) to evaluate air quality. In addition, according to previous research $[26,55,56]$, GHGs (mainly $\mathrm{CO}_{2}$ ), although not classified as air pollutants, also belong to one of the impacts of modular constructions on the air, so they were also included in one of the evaluation indicators. The independent variable was the modular construction policy announced by the two research sites, that is, taking the modular construction policies announced by Singapore in 2000 and Hong Kong in 2002 as time nodes. In terms of the choice of control variables, population has a close relationship with the economy and environment, and changes in population density will have an impact on air quality [57]. GDP is an important tool that reflects the development 
and changes in the national economy and has a very close relationship with economic development and the environment [58]. Industry is the main factor of social and economic activities. The process of industrialisation consumes a lot of fossil energy. The scale of industrial production and energy consumption has a significant impact on air quality [44]. The exhaust emissions of ships (including passenger ships and cargo ships) and motor vehicles also have a very important impact on air quality [59,60].

\subsection{Empirical Specification}

The empirical investigation in this study was conducted in two stages:

First stage: DID model between the two regions:

Since the data of the sample involves multiple variables, the difference in the magnitude of the variable or the severely skewed distribution will cause the regression equation to have higher heteroscedasticity, and the linear relationship is not significant. Therefore, when establishing the DID model, all variables are logarithmic, making the research structure more accurate.

With the control variables, the DID model in this study can be specified as:

$$
\begin{aligned}
\log y_{i t}=a_{0}+ & a_{1} \log M_{i t} \\
& +a_{2} \log \text { Time }_{i t}+a_{3} \log M_{i t} * \text { Time }_{i t}+a_{4} \log \text { Capita }_{i t} \\
& +a_{5} \log \text { Cargo }_{i t}+a_{6} \log \text { Container }_{i t}+a_{7} \log \text { Density }_{i t} \\
& +a_{8} \log \text { Electricity }_{i t}+a_{9} \log \text { Passenger }_{i t}+a_{10} \log _{\text {Value }} \\
& +a_{11} \log \text { Vehicle }_{i t}+\varepsilon_{i t}
\end{aligned}
$$

where Capita represents the annual GDP per capita; Cargo represents the annual cargo transportation of the shipping; Container represents the annual container traffic of the shipping; Density represents the population density of the city; Electricity represents the annual electricity consumption of industry (including construction); Passenger represents

\begin{tabular}{|c|c|c|c|}
\hline Symbols & Control Variables & Descriptions & Unit of Measure \\
\hline Capita & GDP per capita & Logarithm of GDP per capita & Current U.S. dollar per person \\
\hline Cargo & $\begin{array}{c}\text { The annual cargo-handling by } \\
\text { cargo vessels }\end{array}$ & $\begin{array}{l}\text { Logarithm of annual cargo-handling } \\
\text { by cargo vessels }\end{array}$ & Thousand tonnes \\
\hline Container & $\begin{array}{l}\text { The annual container-handling by } \\
\text { container vessels }\end{array}$ & $\begin{array}{l}\text { Logarithm of annual } \\
\text { container-handling by container vessels }\end{array}$ & Thousand twenty-foot equivalent units \\
\hline Density & The population density & Logarithm of population density & People per square kilometre \\
\hline Electricity & $\begin{array}{l}\text { The annual electricity consumption of } \\
\text { industry (including construction) }\end{array}$ & $\begin{array}{l}\text { Logarithm of annual electricity } \\
\text { consumption of industry (including } \\
\text { construction) }\end{array}$ & Ten thousand kilowatt-hours \\
\hline Passenger & $\begin{array}{c}\text { The annual passenger traffic by } \\
\text { passenger vessels }\end{array}$ & $\begin{array}{l}\text { Logarithm of annual passenger traffic } \\
\text { by passenger vessels }\end{array}$ & Thousand passengers \\
\hline Value & $\begin{array}{l}\text { The annual added value of industry } \\
\text { (including construction) }\end{array}$ & $\begin{array}{l}\text { Logarithm of annual added value of } \\
\text { industry (including construction) }\end{array}$ & Percentage \\
\hline Vehicle & The number of motor vehicles & Logarithm of number of motor vehicles & Vehicle \\
\hline
\end{tabular}
the annual passenger traffic of the shipping; Value represents the annual added value of industry (including construction); and Vehicle represents the number of motor vehicles. The setting and description of the control variables of the model are shown in Table 2.

Table 2. Control variables setting and description. 
Second stage: In OLS regression with modular construction policy as the dummy variable, the empirical model can be specified as:

$$
\begin{aligned}
\log y_{i t}=a_{0} \quad+a_{1} \log M_{i t}+a_{2} \log \text { Capita }_{i t}+a_{3} \log \text { Cargo }_{i t} \\
+a_{4} \log \text { Container }_{i t}+a_{5} \log \text { Density }_{i t}+a_{6} \log \text { Electricity }_{i t} \\
+a_{7} \log \text { Passenger }_{i t}+a_{8} \log \text { Value }_{i t}+a_{9} \log \text { Vehicle }_{i t}+\varepsilon_{i t}
\end{aligned}
$$

where Capita represents the annual GDP per capita; Cargo represents the annual cargo transportation of the shipping; Container represents the annual container traffic of the shipping; Density represents the population density of the city; Electricity represents the annual electricity consumption of industry (including construction); Passenger represents the annual passenger traffic of the shipping; Value represents the annual added value of industry (including construction); and Vehicle represents the number of motor vehicles.

The summary statistics of the first stage dataset are shown in Tables 3 and 4.

\begin{tabular}{|c|c|c|c|c|c|c|c|c|}
\hline Variables & GHG & $\mathrm{NO}_{2}$ & $\mathrm{O}_{3}$ & $\mathbf{P M}_{10}$ & $\mathrm{SO}_{2}$ & Policy & Post & DID \\
\hline Mean & 1.948 & 3.71 & 4.783 & 3.707 & 2.9 & - & 0.4 & 0.2 \\
\hline Std.Dev. & 0.338 & 0.335 & 0.061 & 0.219 & 0.165 & - & 0.516 & 0.422 \\
\hline Min & 1.589 & 3.258 & 4.718 & 3.401 & 2.639 & 0 & 0 & 0 \\
\hline Max & 2.293 & 4.127 & 4.890 & 3.951 & 3.091 & 1 & 1 & 1 \\
\hline Sum & 19.483 & 37.095 & 47.833 & 37.067 & 29.003 & - & 4 & 2 \\
\hline Sum Sq. Dev. & 1.069 & 1.061 & 0.193 & 0.693 & 0.521 & - & 1.633 & 1.333 \\
\hline Observations & 10 & 10 & 10 & 10 & 10 & 10 & 10 & 10 \\
\hline Variables & Capita & Cargo & Container & Density & Electricity & Passenger & Value & Vehicle \\
\hline Mean & 10.075 & 12.381 & 9.717 & 8.721 & 13.487 & 9.993 & 2.966 & 13.302 \\
\hline Std.Dev. & 0.074 & 0.322 & 0.085 & 0.039 & 0.43 & 1.287 & 0.508 & 0.16 \\
\hline Min & 9.985 & 12.027 & 9.588 & 8.661 & 13.012 & 8.636 & 2.365 & 13.124 \\
\hline Max & 10.158 & 12.722 & 9.86 & 8.768 & 13.992 & 11.254 & 3.48 & 13.471 \\
\hline Sum & 100.745 & 123.81 & 97.171 & 87.214 & 134.868 & 99.933 & 29.663 & 133.016 \\
\hline Sum Sq. Dev. & 0.233 & 1.017 & 0.270 & 0.123 & 1.360 & 4.071 & 1.605 & 0.506 \\
\hline Observations & 10 & 10 & 10 & 10 & 10 & 10 & 10 & 10 \\
\hline
\end{tabular}

Table 3. Summary statistics of each variable in Singapore (experimental group) and Hong Kong (control group) from 1998 to 2002.

\begin{tabular}{|c|c|c|c|c|c|c|c|c|}
\hline Variables & GHG & $\mathrm{NO}_{2}$ & $\mathrm{O}_{3}$ & $\mathrm{PM}_{10}$ & $\mathrm{SO}_{2}$ & Policy & Post & DID \\
\hline Mean & 1.978 & 3.631 & 4.834 & 3.688 & 2.879 & - & 0.4 & 0.2 \\
\hline Std.Dev. & 0.333 & 0.378 & 0.079 & 0.282 & 0.194 & - & 0.516 & 0.422 \\
\hline Min & 1.589 & 3.178 & 4.718 & 3.332 & 2.639 & 0 & 0 & 0 \\
\hline $\operatorname{Max}$ & 2.322 & 4.078 & 4.984 & 4.094 & 3.219 & 1 & 1 & 1 \\
\hline Sum & 19.780 & 36.310 & 48.342 & 36.875 & 28.786 & - & 4 & 2 \\
\hline Sum Sq. Dev. & 1.053 & 1.195 & 0.250 & 0.891 & 0.612 & - & 1.632993 & 1.333333 \\
\hline Observations & 10 & 10 & 10 & 10 & 10 & 10 & 10 & 10 \\
\hline Variables & Capita & Cargo & Container & Density & Electricity & Passenger & Value & Vehicle \\
\hline Mean & 10.099 & 12.459 & 9.83 & 8.732 & 13.493 & 10.02 & 2.898 & 13.321 \\
\hline Std.Dev. & 0.07 & 0.312 & 0.109 & 0.037 & 0.508 & 1.247 & 0.574 & 0.159 \\
\hline Min & 9.985 & 12.07 & 9.653 & 8.683 & 12.93 & 8.767 & 2.216 & 13.155 \\
\hline Max & 10.226 & 12.883 & 9.998 & 8.773 & 14.014 & 11.25 & 3.48 & 13.497 \\
\hline Sum & 100.985 & 124.591 & 98.301 & 87.319 & 134.928 & 100.199 & 28.980 & 133.215 \\
\hline Sum Sq. Dev. & 0.222 & 0.985 & 0.344 & 0.116 & 1.606 & 3.945 & 1.816 & 0.503 \\
\hline Observations & 10 & 10 & 10 & 10 & 10 & 10 & 10 & 10 \\
\hline
\end{tabular}

Table 4. Summary statistics of each variable in Hong Kong (experimental group) and Singapore (control group) from 2000 to 2004. 
The summary statistics of the second stage dataset are shown in Tables 5 and 6.

Table 5. Summary statistics of each variable in Hong Kong.

\begin{tabular}{|c|c|c|c|c|c|c|c|}
\hline Variables & GHG & $\mathrm{NO}_{2}$ & $\mathrm{O}_{3}$ & $\mathbf{P M}_{10}$ & $\mathrm{SO}_{2}$ & Policy & Capita \\
\hline Mean & 1.736 & 3.938 & 4.842 & 3.842 & 2.645 & - & 10.37 \\
\hline Std.Dev. & 0.075 & 0.108 & 0.058 & 0.167 & 0.367 & - & 0.232 \\
\hline Min & 1.589 & 3.664 & 4.727 & 3.497 & 1.792 & 0 & 10.085 \\
\hline $\operatorname{Max}$ & 1.825 & 4.127 & 4.949 & 4.094 & 3.219 & 1 & 10.793 \\
\hline Sum & 36.459 & 82.690 & 101.686 & 80.672 & 55.538 & - & 217.765 \\
\hline Sum Sq. Dev. & 0.344 & 0.495 & 0.267 & 0.764 & 1.680 & - & 1.064 \\
\hline Observations & 21 & 21 & 21 & 21 & 21 & 21 & 21 \\
\hline Variables & Cargo & Container & Density & Electricity & Passenger & Value & Vehicle \\
\hline Mean & 12.359 & 9.941 & 8.8 & 12.815 & 13.795 & 2.115 & 13.305 \\
\hline Std.Dev. & 0.182 & 0.138 & 0.039 & 0.188 & 0.056 & 0.242 & 0.149 \\
\hline Min & 12.027 & 9.588 & 8.737 & 12.637 & 13.703 & 1.866 & 13.124 \\
\hline $\operatorname{Max}$ & 12.604 & 10.106 & 8.867 & 13.149 & 13.904 & 2.614 & 13.573 \\
\hline Sum & 259.535 & 208.767 & 184.806 & 269.123 & 289.693 & 44.421 & 279.410 \\
\hline Sum Sq. Dev. & 0.834 & 0.633 & 0.177 & 0.862 & 0.256 & 1.108 & 0.681 \\
\hline Observations & 21 & 21 & 21 & 21 & 21 & 21 & 21 \\
\hline
\end{tabular}

Table 6. Summary statistics of each variable in Singapore.

\begin{tabular}{|c|c|c|c|c|c|c|c|}
\hline Variables & GHG & $\mathrm{NO}_{2}$ & $\mathrm{O}_{3}$ & $\mathbf{P M}_{10}$ & $\mathrm{SO}_{2}$ & Policy & Capita \\
\hline Mean & 2.236 & 3.235 & 4.92 & 3.395 & 2.607 & - & 10.537 \\
\hline Std.Dev. & 0.049 & 0.127 & 0.182 & 0.116 & 0.28 & - & 0.405 \\
\hline Min & 2.128 & 3.091 & 4.654 & 3.219 & 2.197 & 0 & 9.985 \\
\hline Max & 2.322 & 3.555 & 5.328 & 3.611 & 3.091 & 1 & 11.076 \\
\hline Sum & 46.957 & 67.939 & 103.323 & 71.291 & 54.745 & - & 221.284 \\
\hline Sum Sq. Dev. & 0.223 & 0.584 & 0.834 & 0.530 & 1.284 & - & 1.857 \\
\hline Observations & 21 & 21 & 21 & 21 & 21 & 21 & 21 \\
\hline Variables & Cargo & Container & Density & Electricity & Passenger & Value & Vehicle \\
\hline Mean & 13.029 & 10.117 & 8.816 & 14.242 & 8.81 & 3.318 & 13.64 \\
\hline Std.Dev. & 0.247 & 0.294 & 0.114 & 0.259 & 0.063 & 0.119 & 0.145 \\
\hline Min & 12.652 & 9.625 & 8.661 & 13.788 & 8.636 & 3.151 & 13.431 \\
\hline Max & 13.354 & 10.508 & 8.962 & 14.582 & 8.92 & 3.48 & 13.789 \\
\hline Sum & 273.614 & 212.458 & 185.132 & 299.085 & 185.008 & 69.678 & 286.440 \\
\hline Sum Sq. Dev. & 1.131 & 1.349 & 0.522 & 1.185 & 0.289 & 0.545 & 0.664 \\
\hline Observations & 21 & 21 & 21 & 21 & 21 & 21 & 21 \\
\hline
\end{tabular}

The unit root test was performed on the time series of the data. The augmented DickeyFuller test results of all the data used in the two locations are provided in Appendices C and D.

\section{Results and Discussion}

\subsection{The DID Result Analysis and Discussion}

5.1.1. The DID Result Analysis and Discussion between Singapore and Hong Kong from 1998 to 2002

The results of DID tests based on the data from Singapore and Hong Kong are shown in Table 7. Figures 1-5 show the DID analysis diagram of each gas between Singapore and Hong Kong from 1998 to 2002.

Table 7 shows that there was no significant effect from any influencing variables on the concentration of the five gases including the modular construction policy. The results demonstrate that population density and the annual added value of industry (including construction) were omitted, indicating that the impact of these two control variables on the emission of GHGs and air pollutants can be ignored. 
Table 7. The DID results between Singapore and Hong Kong from 1998 to 2002.

\begin{tabular}{cccccc}
\hline Variables & GHG & $\mathbf{N O}_{\mathbf{2}}$ & $\mathbf{O}_{\mathbf{3}}$ & $\mathbf{P M}_{\mathbf{1 0}}$ & $\mathbf{S O}_{\mathbf{2}}$ \\
\hline DID & 0.178 & -0.541 & -0.123 & -0.398 & -1.032 \\
Time & -0.0858 & 0.244 & 0.0792 & 0.302 & 0.0258 \\
Policy & -0.00175 & -0.178 & 0.0218 & -0.120 & 0.629 \\
o. Density & - & - & - & - & - \\
Capita & 1.176 & -1.576 & -2.055 & -0.932 & -9.782 \\
o. Value & - & - & - & - & - \\
Electricity & -0.558 & 2.117 & 0.857 & 2.003 & 1.811 \\
Vehicle & 0.678 & -4.238 & -0.116 & -5.895 & 0.263 \\
Passenger & 0.0286 & 0.118 & 0.194 & -0.350 & 0.450 \\
Cargo & 1.627 & -0.992 & -0.599 & -1.514 & -2.209 \\
Container & -0.870 & 0.411 & 0.445 & 1.074 & 1.080 \\
Constant & -23.37 & 54.57 & 16.60 & 76.30 & 85.89 \\
Observations & & & 10 & & \\
R-squared & & & 1.000 & &
\end{tabular}

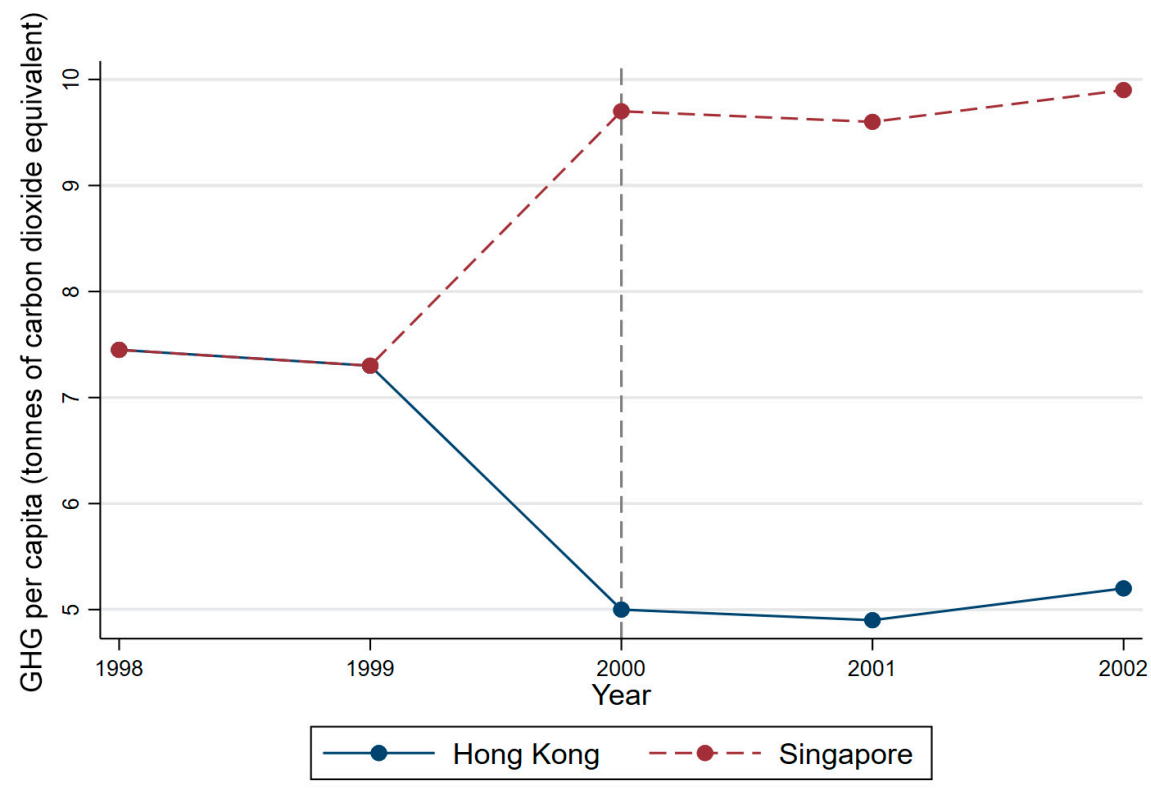

Figure 1. The GHG per capita between Singapore and Hong Kong from 1998 to 2002.

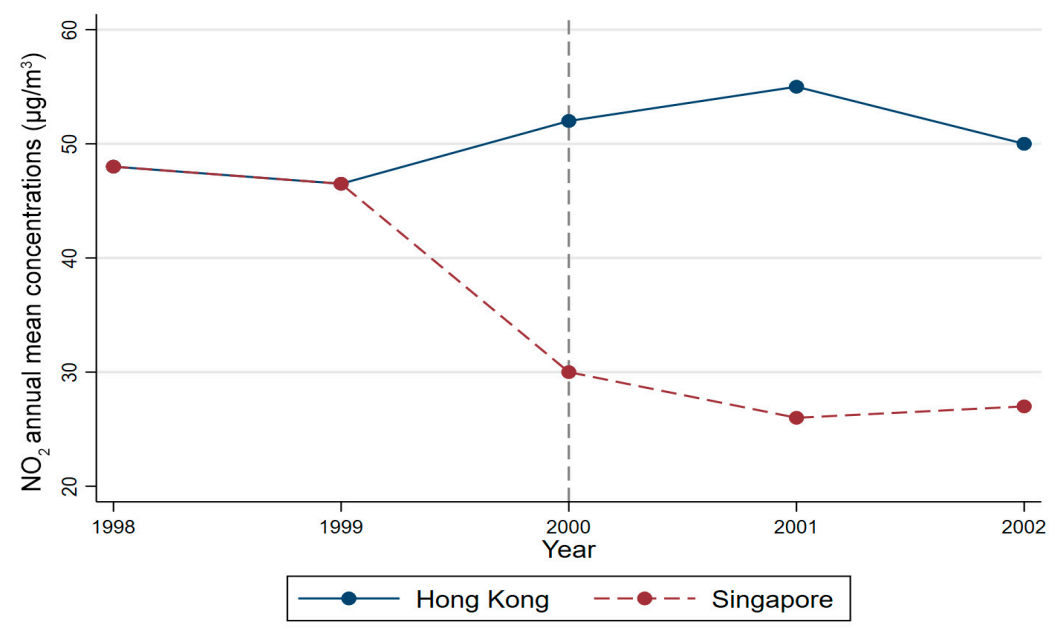

Figure 2. The $\mathrm{NO}_{2}$ annual mean concentrations between Singapore and Hong Kong from 1998 to 2002. 


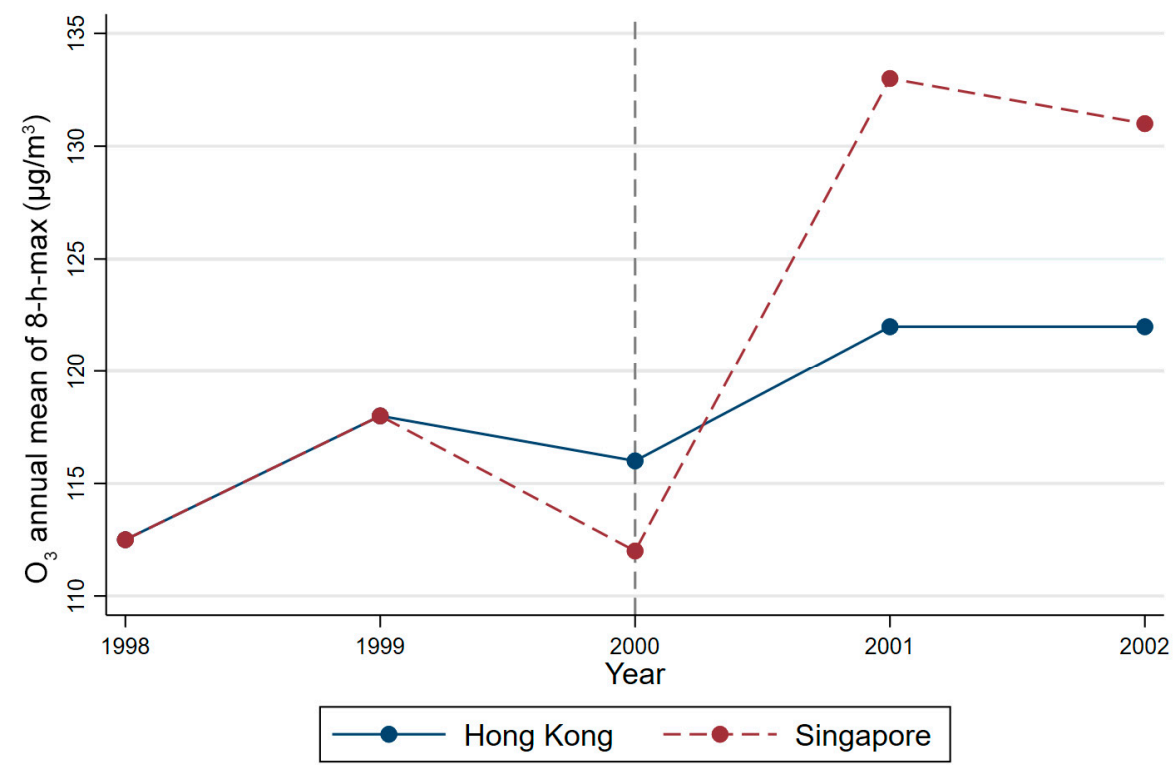

Figure 3. The $\mathrm{O}_{3}$ annual mean of 8-h max between Singapore and Hong Kong from 1998 to 2002.

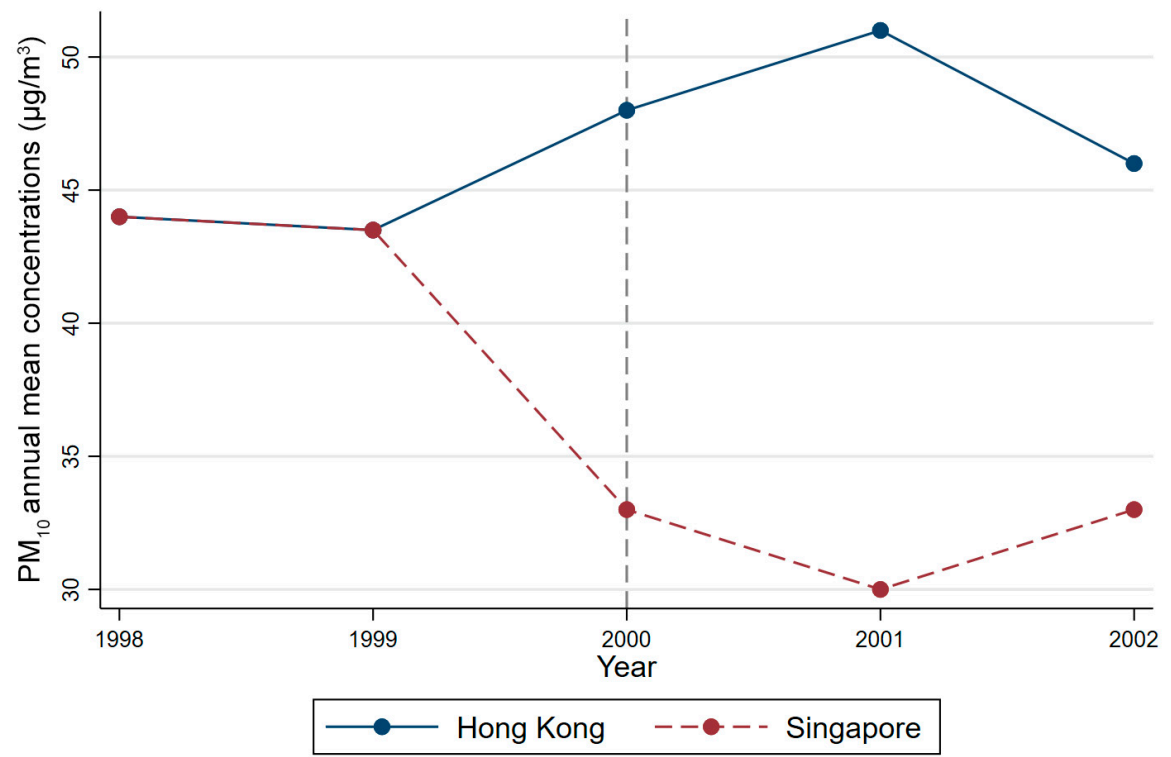

Figure 4. The $\mathrm{PM}_{10}$ annual mean concentrations between Singapore and Hong Kong from 1998 to 2002.

Figure 1 shows that Singapore's GHG per capita emissions after 2000 rose significantly and reached the highest value of 9.9 tonnes of carbon dioxide equivalent per capita in 2002. The coefficient of DID was 0.178 , indicating that the modular construction policy had a positive impact on GHG emissions, and the effect of annual container-handling by container vessels on reducing GHG emissions was obvious $(-0.870)$ (Table 7). The positive effects of annual cargo-handling by cargo vessels and GDP per capita on GHG emissions were relatively effective at 1.627 and 1.176, respectively. In contrast, Hong Kong has not adopted a modular construction policy, but GHG emissions reached the lowest point in 2001 at 4.9 tonnes of carbon dioxide equivalent per capita.

Figure 2 shows that the annual mean concentration of NO2 in Singapore significantly decreased and reached the lowest value of $26 \mu \mathrm{g} / \mathrm{m}^{3}$ in 2001. However, Hong Kong continued to grow, reaching the highest value of $55 \mu \mathrm{g} / \mathrm{m}^{3}$ in 2001 . The results of DID show that the modular construction policy only had a weak reduction effect on $\mathrm{NO}_{2}$ emissions, which was -0.541 (Table 7). Compared with the policy, the change in the number of motor vehicles had a more obvious impact on $\mathrm{NO}_{2}$ emissions, which was -4.238 . The annual 
electricity consumption of industry (including construction) had the greatest positive impact on $\mathrm{NO}_{2}$ emissions, which was 2.117 (Table 7).

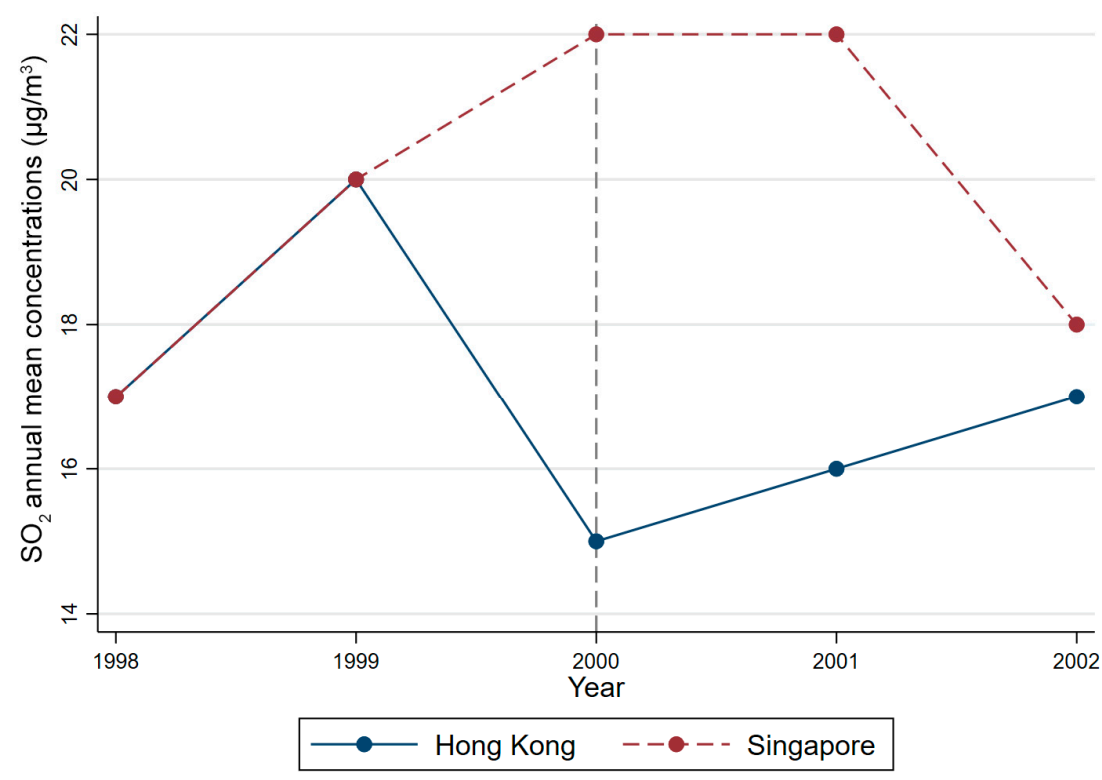

Figure 5. The $\mathrm{SO}_{2}$ annual mean concentrations between Singapore and Hong Kong from 1998 to 2002.

The modular construction policy has no significant impact on Singapore's $\mathrm{O}_{3}$ concentration, with a value of -0.123 (Table 7 ). The annual electricity consumption of industry (including construction) had the greatest positive impact on $\mathrm{O}_{3}$ emissions, at 0.857 GDP per capita, it had a relatively significant effect on the decrease in $\mathrm{O}_{3}$ concentration at -2.055 . In 2000, Singapore's $\mathrm{O}_{3}$ annual mean of 8-h max had a short-term decline, reaching the lowest point of $112 \mu \mathrm{g} / \mathrm{m}^{3}$ (Figure 3). However, there was a significant increase in $2001\left(133 \mu \mathrm{g} / \mathrm{m}^{3}\right)$, and since then, it has been higher than the $\mathrm{O}_{3}$ annual mean of 8-h max in Hong Kong.

The annual mean concentration of $\mathrm{PM}_{10}$ in Singapore dropped significantly in 2000 and reached the lowest point of $30 \mu \mathrm{g} / \mathrm{m}^{3}$ in 2001, while the $\mathrm{PM}_{10}$ in Hong Kong kept rising and reached the highest value of $51 \mu \mathrm{g} / \mathrm{m}^{3}$ in 2001 (Figure 4). Modular construction policy is still not the main reason for the decline in $\mathrm{PM}_{10}$ in Singapore. Its coefficient was only -0.398 , while the number of motor vehicles had the best effect on reducing $\mathrm{PM}_{10}$, which was -5.895 (Table 7). The annual electricity consumption of industry (including construction) and the annual container-handling by container vessels contributed significantly to the $\mathrm{PM}_{10}$ emissions, which were 2.003 and 1.074, respectively (Table 7).

As shown in Table 7, although the modular construction policy had no significant impact on these five gases, the impact of the policy on Singapore's $\mathrm{SO}_{2}$ was the most obvious of these five gases, at -1.032 . The $\mathrm{SO}_{2}$ concentration in Singapore remained at $22 \mu \mathrm{g} / \mathrm{m}^{3}$ in 2000 and 2001 (Figure 5). GDP per capita was the variable that promoted $\mathrm{SO}_{2}$ emissions the most among the eight control variables, which was -9.782 . The annual cargo-handling by cargo vessels also promoted the reduction in $\mathrm{SO}_{2}$ emissions, which was -2.209 . The annual electricity consumption of industry (including construction) and the annual container-handling by the container vessels contribution to $\mathrm{SO}_{2}$ emissions were greater, which were 1.811 and 1.080 , respectively.

5.1.2. The DID Result Analysis and Discussion between Singapore and Hong Kong from 1998 to 2002

The results of the DID test based on the data from Singapore and Hong Kong are shown in Table 8. Figures 6-10 show the DID analysis diagram of each gas compared between Hong Kong and Singapore from 2000 to 2004. 
Table 8. The DID results between Hong Kong and Singapore from 2000 to 2004

\begin{tabular}{cccccc}
\hline Variables & GHG & $\mathbf{N O}_{\mathbf{2}}$ & $\mathbf{O}_{\mathbf{3}}$ & $\mathbf{P M}_{\mathbf{1 0}}$ & $\mathbf{S O}_{\mathbf{2}}$ \\
\hline DID & 0.106 & 0.326 & -0.232 & 0.252 & 1.569 \\
Time & -0.00254 & -0.357 & 0.221 & -0.293 & -0.968 \\
& $(0)$ & $(0)$ & $(0)$ & $(0)$ & $(0)$ \\
Policy & 0.0653 & -0.107 & -0.185 & -0.260 & 0.802 \\
o. Density & - & - & - & - & - \\
Capita & 0.00258 & 2.721 & -3.557 & 0.116 & 16.77 \\
Value & 0.161 & -1.957 & 2.320 & -0.837 & -9.643 \\
Electricity & 0.228 & -0.186 & -0.378 & -0.447 & 4.242 \\
o. Vehicle & - & - & - & - & - \\
Passenger & -0.0928 & -0.980 & 2.080 & -0.347 & -3.957 \\
Cargo & 0.169 & -0.901 & 4.070 & 0.0989 & -3.098 \\
Container & 0.0194 & 0.244 & -1.312 & 1.172 & -7.620 \\
Constant & -3.004 & 3.092 & -19.50 & 1.836 & -42.73 \\
\hline Observations & & & 10 & & \\
R-squared & & & 1.000 & & \\
\hline
\end{tabular}

Table 8 shows that the effect of the modular construction policy on the five gases was not significant, and none of the influencing variables had an impact on the concentration of the five gases. The results show that the results of population density and the number of motor vehicles were omitted, indicating that these two control variables have negligible effects on GHGs and air pollutant emissions. The following is an analysis of the results of each gas.

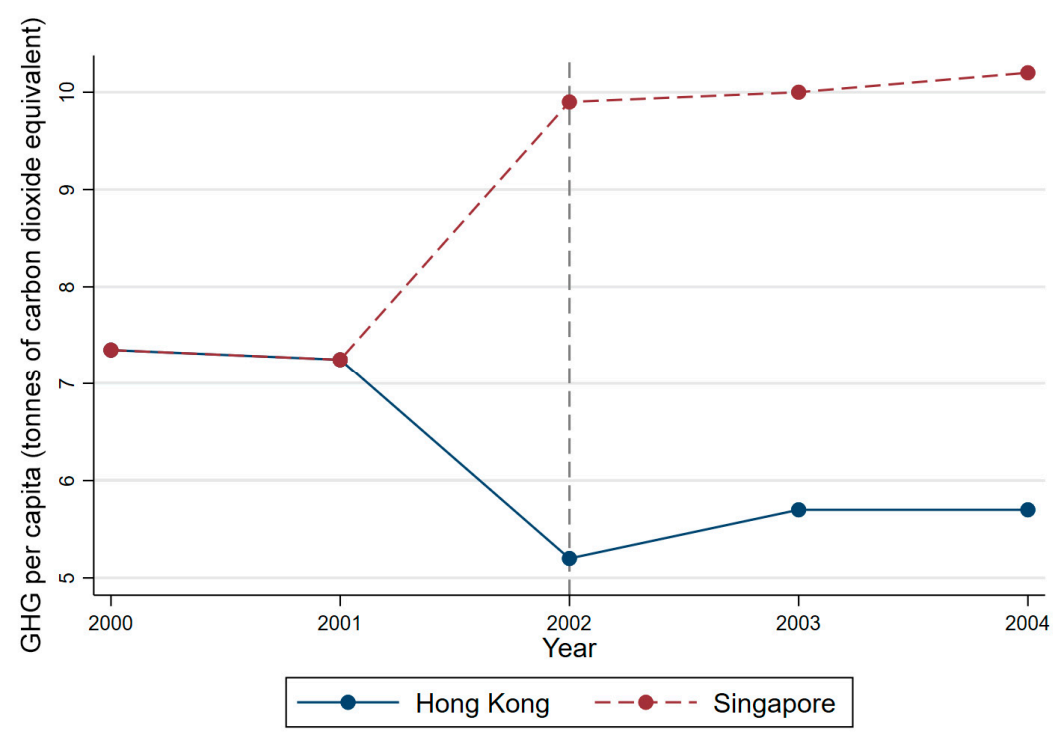

Figure 6. The GHG per capita between Hong Kong and Singapore from 2000 to 2004.

Figure 6 shows that Hong Kong's GHG per capita emissions underwent significant changes after 2002. However, except for the annual passenger traffic by passenger vessels, which has a negative impact on GHG emissions (-0.0928), the other variables were all positive (Table 8). The annual electricity consumption of industry (including construction) and the annual cargo-handling by cargo vessels contributed significantly to GHG emissions, which were 0.228 and 0.169 , respectively. Modular construction policy also had a positive impact on GHG emissions and the DID value was 0.106 (Table 8). 


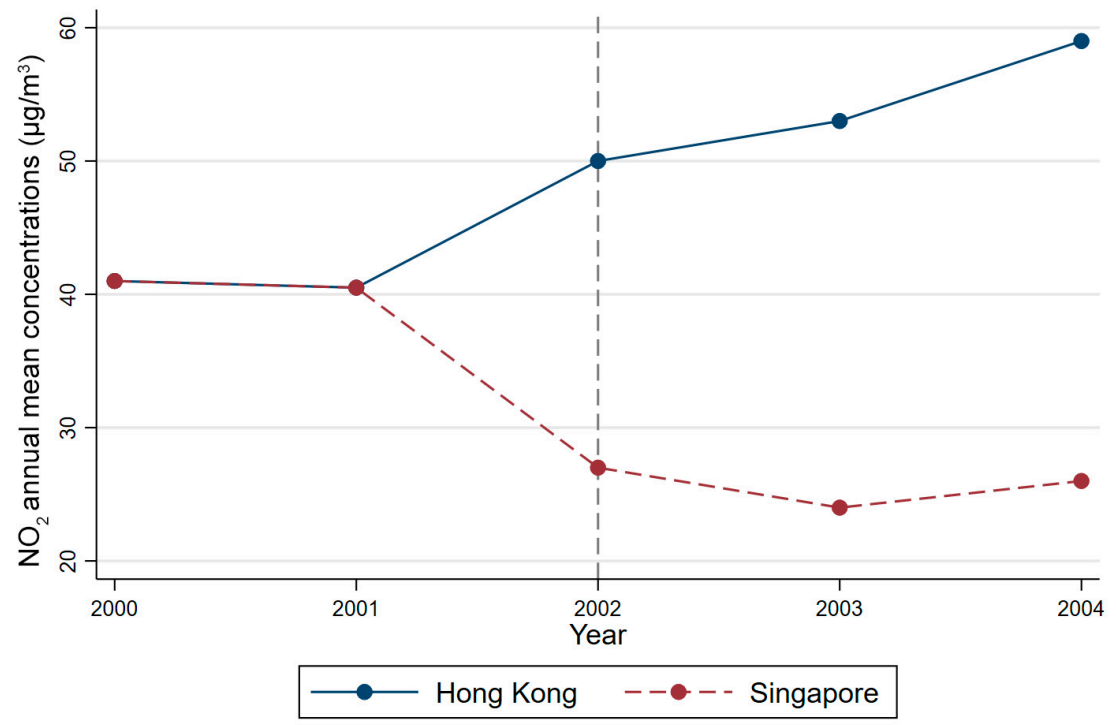

Figure 7. The $\mathrm{NO}_{2}$ annual mean concentrations between Hong Kong and Singapore from 2000 to 2004.

The $\mathrm{NO}_{2}$ concentration in Hong Kong rose instead of falling after 2002, reaching the highest point of $59 \mu \mathrm{g} / \mathrm{m}^{3}$ in 2004 (Figure 7). The modular construction policy (0.326) can promote $\mathrm{NO}_{2}$ emissions, and the GDP per capita (2.721) and the annual containerhandling by container vessels (0.244) can also increase the $\mathrm{NO}_{2}$ concentration (Table 8). Although most of the control variables could suppress $\mathrm{NO}_{2}$ emissions, their impacts were not significant, and the $\mathrm{NO}_{2}$ concentration is still increasing.

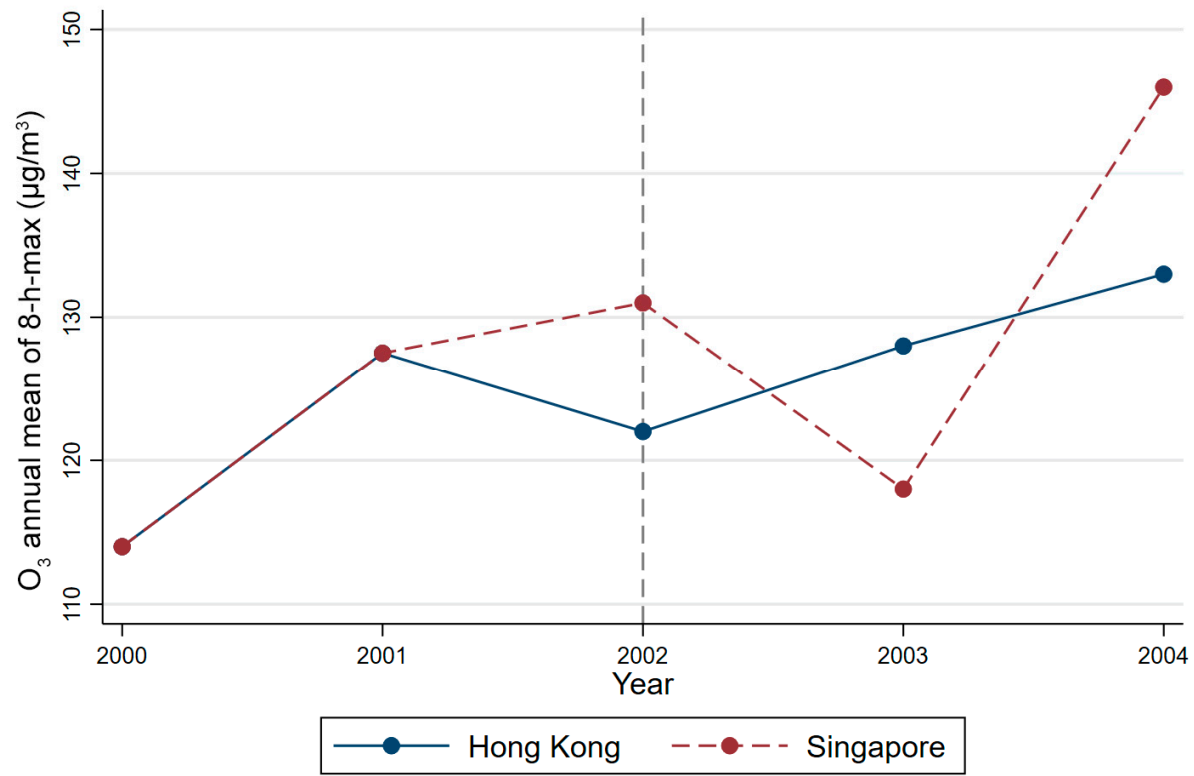

Figure 8. The $\mathrm{O}_{3}$ annual mean of 8-h max between Hong Kong and Singapore from 2000 to 2004.

The trend of $\mathrm{O}_{3}$ in Hong Kong continued to rise after a brief decline in 2002 and reached the highest value of $133 \mu \mathrm{g} / \mathrm{m}^{3}$ in 2004 (Figure 8). The modular construction policy $(-0.232)$ can reduce the increase in $\mathrm{O}_{3}$ concentration, but its effect was not significant (Table 8). GDP per capita (-3.557) was the control variable that had the greatest impact on $\mathrm{O}_{3}$ concentration, and can inhibit the increase in $\mathrm{O}_{3}$ concentration. The annual cargohandling by cargo vessels is the most important control variable (4.070) that promotes the increase in $\mathrm{O}_{3}$ concentration. 


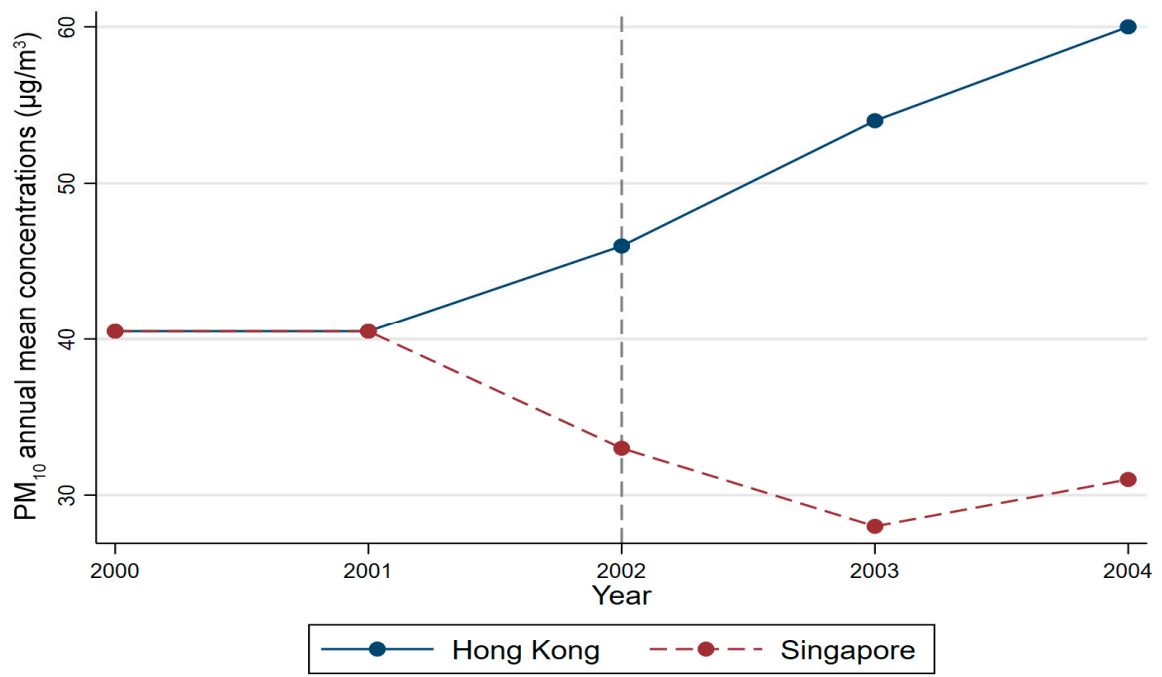

Figure 9. The $\mathrm{PM}_{10}$ annual mean concentrations between Hong Kong and Singapore from 2000 to 2004.

After the implementation of the modular construction policy in Hong Kong in 2002, the $\mathrm{PM}_{10}$ concentration did not decrease but increased to $60 \mu \mathrm{g} / \mathrm{m}^{3}$. Singapore continued to decline and reached the lowest value of $28 \mu \mathrm{g} / \mathrm{m}^{3}$ in 2003, and then in 2004, rebounded to $31 \mu \mathrm{g} / \mathrm{m}^{3}$ (Figure 9). The modular construction policy $(0.252)$ promoted $\mathrm{PM}_{10}$ emissions (Table 8). The annual container-handling by container vessels (1.172), GDP per capita (0.116), and the annual cargo-handling by cargo vessels (0.0989) were all positively correlated with $\mathrm{PM}_{10}$ emissions. The annual added value of industry (including construction) $(-0.837)$, the annual electricity consumption of industry (including construction) $(-0.447)$, and the annual passenger traffic by passenger vessels $(-0.347)$ all contribute to reducing $\mathrm{PM}_{10}$ emissions.

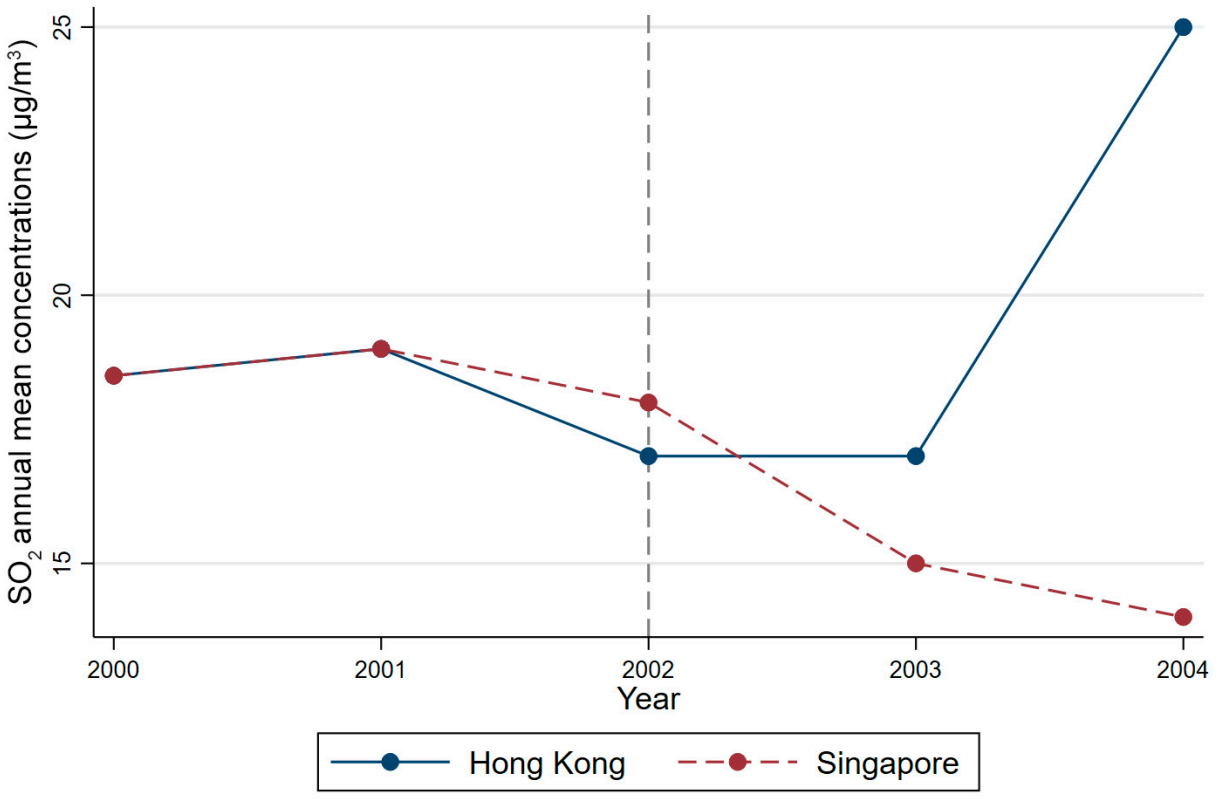

Figure 10. The $\mathrm{SO}_{2}$ annual mean concentrations between Hong Kong and Singapore from 2000 to 2004 .

In 2002, the concentration of $\mathrm{SO}_{2}$ in Hong Kong dropped briefly to $17 \mu \mathrm{g} / \mathrm{m}^{3}$ and remained until 2003. However, in 2004, it suddenly rose to $25 \mu \mathrm{g} / \mathrm{m}^{3}$, while the $\mathrm{SO}_{2}$ in Singapore continued to decline, reaching $14 \mu \mathrm{g} / \mathrm{m}^{3}$ in 2004 (Figure 10). The modular construction policy still had no significant impact on the $\mathrm{SO}_{2}$ concentration, but compared to the other four gases, the policy's impact coefficient on the $\mathrm{SO}_{2}$ concentration was significantly higher, which was 1.569 (Table 8). The influence coefficient of GDP per capita (16.77) and the annual electricity consumption of industry (including construction) (4.242) have 
increased significantly. Other control variables such as the annual added value of industry (including construction) (-9.643) and the annual container-handling by container vessels $(-7.620)$ had an inhibitory effect on the increase in $\mathrm{SO}_{2}$ concentration.

The DID results between Singapore and Hong Kong from 1998 to 2002 and the DID results between Hong Kong and Singapore from 2000 to 2004 showed that the effect of the modular construction policy on the five gas emissions in Hong Kong and Singapore was not significant (Tables 7 and 8). This result may be related to the fact that the modular construction policy has no effect on the scale. In the two analyses, although the policy has a certain reduction effect on $\mathrm{O}_{3}$ emissions, one needs to be vigilant as the modular construction policy may promote GHG emissions.

\subsection{The OLS Results Analysis and Discussion}

5.2.1. The OLS Results Analysis and Discussion of Hong Kong from 1998 to 2018

In stage two, this study continued to use Stata 16.0 for OLS regression analysis. After substituting the relevant data of Hong Kong from 1998 to 2018, the OLS regression results obtained are shown in Table 9. Figures 11-13 show the OLS regression analysis diagram of each gas in Hong Kong from 1998 to 2018.

Table 9. The OLS regression results of Hong Kong from 1998 to 2018.

\begin{tabular}{cccccc}
\hline Variables & GHG & $\mathbf{N O}_{\mathbf{2}}$ & $\mathbf{O}_{\mathbf{3}}$ & $\mathbf{P M}_{\mathbf{1 0}}$ & $\mathbf{S O}_{\mathbf{2}}$ \\
\hline Density & $-8.400^{* *}$ & $-21.98^{* *}$ & 6.219 & $-18.18^{* * *}$ & -6.146 \\
Capita & 0.0705 & -0.00836 & $-0.905^{* * *}$ & $-0.734^{*}$ & 0.520 \\
Value & $-0.647^{* * *}$ & -0.0922 & -0.0720 & $-0.768^{*}$ & 0.0764 \\
Electricity & $2.130^{*}$ & 3.517 & -1.807 & 3.556 & $16.70^{* *}$ \\
Vehicle & $3.894^{*}$ & $10.87^{*}$ & -3.314 & $8.853^{* *}$ & $23.73^{*}$ \\
Passenger & -4.172 & -9.824 & 4.735 & -7.378 & $-37.79^{* *}$ \\
Cargo & $0.852^{* * *}$ & -0.0966 & $0.500^{*}$ & 0.435 & 1.177 \\
Container & $-0.537^{* *}$ & 0.161 & -0.367 & -0.0662 & -0.459 \\
1. Policy & 0.0343 & -0.0393 & -0.0356 & $-0.0714^{*}$ & -0.0631 \\
Constant & $49.55^{* *}$ & $143.1^{* *}$ & $-40.94 *$ & $106.8^{* * *}$ & 32.87 \\
Observations & & & 21 & & \\
R-squared & 0.950 & 0.830 & 0.875 & 0.967 & 0.941 \\
\hline Standard errors in parentheses ${ }^{* * *} p<0.011^{* *} p<0.05,{ }^{*} p<0.1$.
\end{tabular}

Table 9 shows that the modular construction policy had a significant impact on Hong Kong's $\mathrm{PM}_{10}$ emissions reduction effect, but had no significant impact on the other four gases, and other control variables had a significant impact on individual gases. The following is an analysis of the results of each gas.

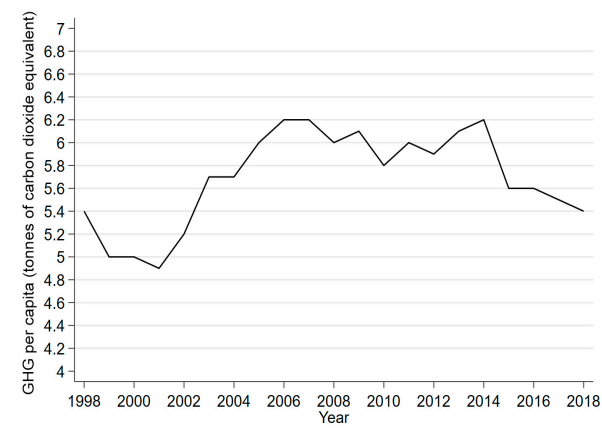

(a)

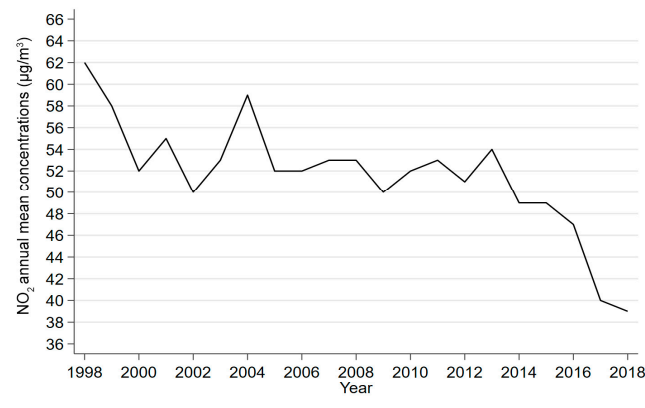

(b)

Figure 11. The GHG per capita (a) and $\mathrm{NO}_{2}(\mathbf{b})$ annual mean concentrations in Hong Kong from 1998 to 2018. 


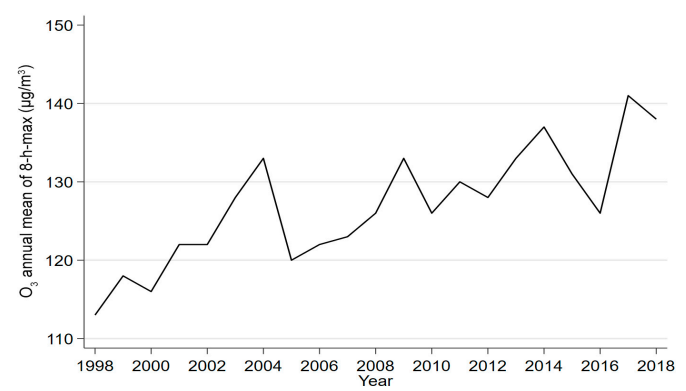

Figure 12. The $\mathrm{O}_{3}$ annual mean of 8-h max of Hong Kong from 1998 to 2018.

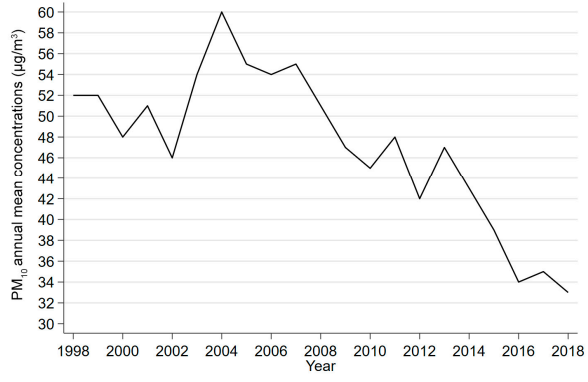

(a)

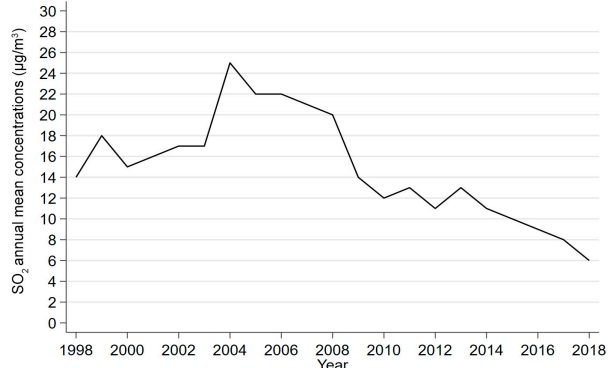

(b)

Figure 13. The $\mathrm{PM}_{10}(\mathbf{a})$ and $\mathrm{SO}_{2}$ (b) annual mean concentrations in Hong Kong from 1998 to 2018.

After Hong Kong adopted the modular construction policy in 2002, both GHG per capita and $\mathrm{NO}_{2}$ annual mean concentrations kept increasing for several years. However, it showed a downwards long-term trend in emissions over time, especially after 2014 (Figure 11).

Figure 12 shows that after 2002, the $\mathrm{O}_{3}$ annual mean of 8-h max in Hong Kong kept climbing. Although there were two significant decreases in 2005 and 2016, the $\mathrm{O}_{3}$ annual mean of 8-h max still increased.

As shown in Figure 13, both $\mathrm{PM}_{10}$ and $\mathrm{SO}_{2}$ annual mean concentration saw changes after the implementation of the modular construction policy, although statistically, only $\mathrm{PM}_{10}$ annual mean concentrations had been significantly affected by the policy.

\subsubsection{The OLS Results Analysis and Discussion of Singapore from 1998 to 2018}

Stata 16.0 for OLS was used for regression analysis. After substituting the relevant data of Singapore from 1998 to 2018, the OLS regression results obtained are shown in Table 10. Figures 14-16 show the OLS regression analysis diagram of each gas in Singapore from 1998 to 2018.

Table 10 shows that the modular construction policy had no significant impact on the five gases in Singapore. Except for population density, the annual cargo-handling by cargo vessels, and the annual container-handling by container vessels, other control variables had some significant effects on each gas. The following is an analysis of the results of each gas.

After Singapore adopted the modular construction policy in 2000, both GHG per capita and $\mathrm{PM}_{10}$ annual mean concentrations fluctuated in the past few years. However, with the passage of time, its emissions reduction effect began to weaken, and the concentration of GHG per capita and $\mathrm{PM}_{10}$ began to rebound and rise, which was close to the level of 2000 (Figure 14).

Figure 15 shows that the $\mathrm{O}_{3}$ annual mean of 8-h max of Singapore had a violent rise after 2000 and reached the highest value in 2007. Although it dropped significantly in 2009, it still shows a long-term upward trend in the future.

As shown in Figure 16, both the $\mathrm{NO}_{2}$ and $\mathrm{SO}_{2}$ annual mean concentrations in Singapore after 2000 have dropped significantly after 2000 . Although statistically the impact of modular construction policy on these two gases is not significant, after 2000, both the $\mathrm{NO}_{2}$ and $\mathrm{SO}_{2}$ annual mean concentrations have dropped. 
Table 10. The OLS regression results of Singapore from 1998 to 2018.

\begin{tabular}{cccccc}
\hline Variables & GHG & $\mathbf{N O}_{\mathbf{2}}$ & $\mathbf{O}_{\mathbf{3}}$ & $\mathbf{P M}_{\mathbf{1 0}}$ & $\mathbf{S O}_{\mathbf{2}}$ \\
\hline Density & -0.571 & 1.718 & -3.205 & 2.109 & -0.342 \\
Capita & $0.398^{* *}$ & $0.801^{* *}$ & -0.407 & 0.199 & 1.034 \\
Value & -0.0246 & 0.180 & -1.363 & 1.119 & $-2.671^{* *}$ \\
Electricity & $0.371^{* *}$ & $-1.186^{* * *}$ & 0.570 & -0.658 & -0.188 \\
Vehicle & $-0.790^{* *}$ & $-2.263^{* * *}$ & -0.536 & -0.701 & $-2.991^{*}$ \\
Passenger & 0.0787 & $-0.547^{*}$ & 0.586 & -0.335 & 0.229 \\
Cargo & -0.315 & 0.663 & 1.156 & 0.257 & -1.643 \\
Container & -0.125 & -0.333 & 0.231 & -0.137 & -0.102 \\
1. Policy & 0.0139 & -0.0100 & 0.0260 & 0.0548 & 0.0353 \\
Constant & $13.32^{* * *}$ & $26.37^{* *}$ & 18.61 & -1.110 & $67.47^{* * *}$ \\
Observations & & & 21 & & \\
R-squared & 0.874 & 0.898 & 0.571 & 0.498 & 0.886 \\
\hline Standard errors in parentheses ${ }^{* * *} p<0.011^{* *} p<0.05,{ }^{*} p<0.1$. &
\end{tabular}

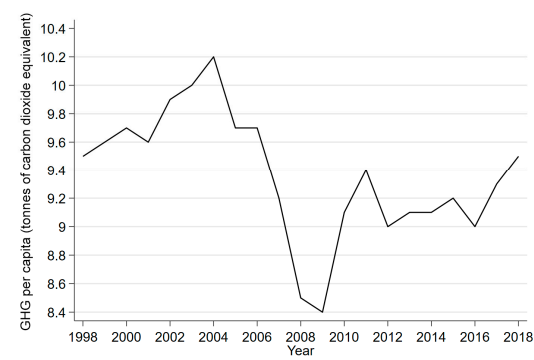

(a)

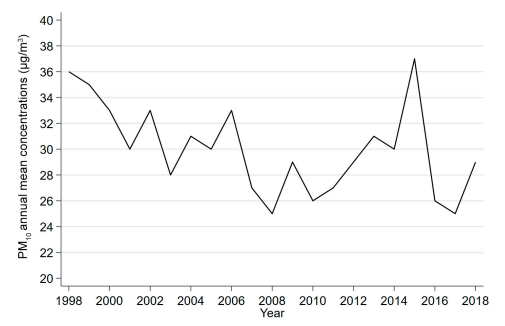

(b)

Figure 14. The GHG per capita (a) and $\mathrm{PM}_{10}$ (b) annual mean concentrations in Singapore from 1998 to 2018 .

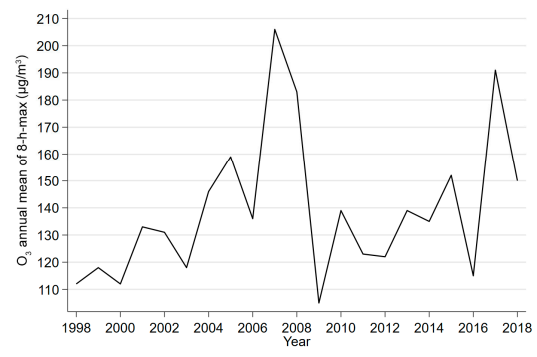

Figure 15. The $\mathrm{O}_{3}$ annual mean of 8-h max of Singapore from 1998 to 2018.

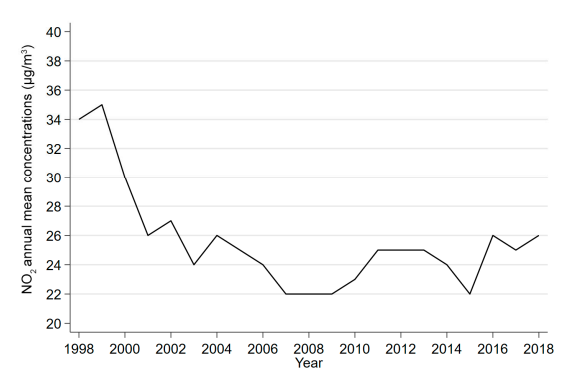

(a)

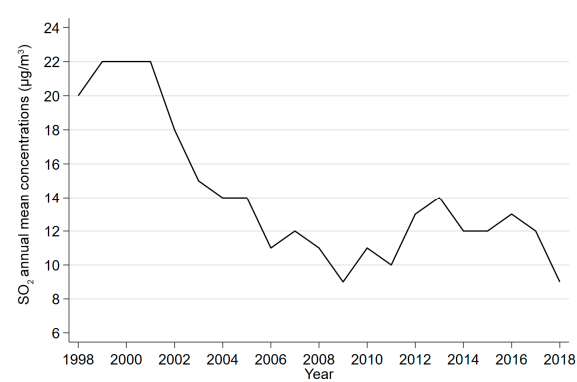

(b)

Figure 16. The $\mathrm{NO}_{2}(\mathbf{a})$ and $\mathrm{SO}_{2}(\mathbf{b})$ annual mean concentrations in Singapore from 1998 to 2018.

The results of Tables 9 and 10 are basically consistent with the analysis results of DID (Tables 7 and 8), that is, the modular construction policy cannot have a significant impact on the five types of gas emissions, but it also has a certain role in promoting GHG emissions. However, it is worth noting that this policy has a significant effect on the reduction in $\mathrm{PM}_{10}$ in Hong Kong, indicating that this policy has a reduction effect on the emissions of 
$\mathrm{PM}_{10}$ in Hong Kong. However, in Table 10, this policy has a promoting effect on $\mathrm{PM}_{10}$ in Singapore. This shows that this policy is not universal for $\mathrm{PM}_{10}$ emissions reduction, and further specific analysis is needed.

\section{Conclusions and Implications}

This study explores the impact of modular construction practice on GHGs and air pollutant emissions in Hong Kong and Singapore through policy implementation. This finding differs from the previous studies in this area. It was found that in addition to Hong Kong's $\mathrm{PM}_{10}$ being significantly negatively affected, that is, the implementation of the modular construction policy can reduce Hong Kong's $\mathrm{PM}_{10}$ concentration, the modular construction policy had an impact on Hong Kong's GHGs, $\mathrm{NO}_{2}, \mathrm{O}_{3}$, and $\mathrm{SO}_{2}$ and the GHGs, $\mathrm{NO}_{2}, \mathrm{O}_{3}, \mathrm{PM}_{10}$, and $\mathrm{SO}_{2}$ in Singapore were not significant. It shows that the modular construction policy implementation has limited impact on the air quality of these cities and cannot effectively improve the air quality of these regions.

This study aims to contribute to the existing knowledge body by comparing and analysing the modular construction policies in Hong Kong and Singapore and evaluating the impact of the policy on air quality in the two cities. The contribution of this paper is that it was conducted based on the city scope, which is a much bigger scale than a single building, and there are many factors that affect the air quality in the city. This research provides a way to explore the impact of modular construction policies on regional air quality in the future. By evaluating the performance of modular constructions on regional air quality, it can help policy makers formulate more reasonable policies and rationally evaluate modular constructions. For the sustainability performance at the regional level, we can explore its impact on the environment to determine whether or not to implement it.

According to the empirical results, the modular construction policy can improve air quality to some extent. Particularly in Hong Kong, the results show that the modular construction policy can reduce the concentration of $\mathrm{PM}_{10}$ in Hong Kong. However, it should also be considered that the modular construction policy has not been widely applied to limit its impact on air quality. There are few public and private buildings using modular construction technology, and the improvement in regional air quality by modular construction is still very limited. This shows that from policy formulation to implementation, it will take a long time to finally form a scale effect, that is, it will take a long time to improve air quality through a modular construction policy. Besides, the long project cycle is also one of the other possible reasons for the insignificant results. According to the research by Chan [61], the construction period of every HK\$1 million construction project in Hong Kong is 152 days. The average period of each project in Hong Kong is three years [5], while the average period of construction projects constructed in Singapore using traditional methods is 2.5 to three years [62]. Although using modular construction technology can shorten the construction project time [5], within three years after the implementation of the modularisation policy, only a small number of construction projects using modular construction technology have been completed, which may also lead to the limited impact of the policy on local air quality. In addition, according to the OLS analysis results of Hong Kong and Singapore, the annual electricity consumption of industry (including construction), the annual passenger traffic by passenger vessels, and the number of motor vehicles has a significant impact on GHGs and air pollutant emissions. Therefore, when controlling policies to improve air quality, these three factors need to be considered by policymakers. In future, the research scope can be changed or expanded to explore the impact of modular construction policies on air quality in different regions.

Author Contributions: Conceptualisation, R.Z. and Y.X.; Methodology, R.Z. and Y.X.; Validation, R.Z. and Y.X.; Formal analysis, R.Z. and Y.X.; Investigation, R.Z. and Y.X.; Resources, R.Z. and Y.X.; Data curation, R.Z. and Y.X.; Writing-original draft preparation, R.Z.; Writing-review and editing, R.Z. and Y.X.; Visualisation, R.Z. and Y.X.; Supervision, Y.X.; Project administration, R.Z. and Y.X. All authors have read and agreed to the published version of the manuscript. 
Funding: This research received no external funding.

Institutional Review Board Statement: Not applicable.

Informed Consent Statement: Not applicable.

Data Availability Statement: All data, models, and code that support the findings of this study are available from the corresponding author upon reasonable request.

Acknowledgments: Our thanks go to Corinne Baulcomb, Paula Novo, Junming Zhu, Weiqiang Chen, and Xinyi Guo for their suggestions on this article. We also thank the University of Edinburgh, Scotland's Rural College, and the University of Manchester for their help and allowing us to use the school's resources to complete this article during the COVID-19 lockdown.

Conflicts of Interest: The authors declare no conflict of interest.

\section{Appendix A. Development of Hong Kong's Modular Construction}

Table A1. Development of Hong Kong's Modular Construction.

\begin{tabular}{|c|c|c|}
\hline Policy/Regulation/Code & Key Contents & References \\
\hline Joint Practice Note No. 1 & $\begin{array}{l}\text { The cumulative total building area exemption of all green functions (excluding sky } \\
\text { garden and podium garden) should not exceed } 8 \% \text { of the total permitted building } \\
\text { area of the development project. }\end{array}$ & [63] \\
\hline Joint Practice Note No. 2 & $\begin{array}{l}\text { If the conditions are met, non-structural prefabricated exterior walls and modular } \\
\text { integrated buildings can be exempted from total floor area and/or site coverage. }\end{array}$ & [64] \\
\hline \multirow{2}{*}{$\begin{array}{l}\text { Code of Practice for Precast } \\
\text { Concrete Construction }\end{array}$} & $\begin{array}{l}\text { As far as possible, the use of standardised precast concrete components should be } \\
\text { planned for buildings that use precast concrete buildings. }\end{array}$ & [65] \\
\hline & Increased production tolerances and installation tolerances & [66] \\
\hline
\end{tabular}

\section{Appendix B. Development of Singapore's Modular Construction}

Table A2. Development of Hong Kong's Modular Construction.

Policy/Regulation/Code

If the submitted buildability score is lower than the minimum required score, it will not be approved.

Prefabricated components have been incorporated into the practice guidelines, and the use

of prefabricated components can increase the buildability score of the building.

The minimum buildability score requirement remains unchanged. Adjustment of influencing factors.

The minimum buildability score requirement is increased. Adjustment of influencing factors.

The minimum buildability score requirement is increased. Adjustment of influencing

Code of Practice on Buildable Design factors. Use prefabricated parts to gain extra points

The minimum buildability score requirement is increased. The Constructability Appraisal System (CAS) is newly added, and it is used as the building evaluation standard together with the Buildable Design Appraisal System (BDAS).

The minimum constructability score requirement is increased. Adjustment of influencing factors. The minimum constructability score is increased.

The minimum constructability score requirement is increased. Adjustment of influencing factors. The minimum constructability score is increased.

The minimum constructability score requirement is increased. Adjustment of influencing factors. The minimum constructability score is increased.

The minimum constructability score requirement remains unchanged, and the minimum constructability score remains unchanged. Added the minimum buildable design score for the basement of all new construction projects. 


\section{Appendix C. Augmented Dickey-Fuller Test of Unit Root of Each Variable in Hong Kong}

Table A3. Augmented Dickey-Fuller Test of Unit Root of Each Variable in Hong Kong.

\begin{tabular}{|c|c|c|c|c|}
\hline Variables & Test Statistic & $1 \%$ Critical Value & $\begin{array}{c}\text { Augmented Dickey-Fuller } \\
5 \% \text { Critical Value }\end{array}$ & $10 \%$ Critical Value \\
\hline$Z(t)_{\text {ln_Capita }}{ }^{1}$ & 1.774 & -3.750 & -3.000 & -2.630 \\
\hline$Z(t)_{\ln \operatorname{Cargo}_{0}} 2$ & -1.884 & -3.750 & -3.000 & -2.630 \\
\hline$Z(t)_{\ln \text { Container }}{ }^{3}$ & -3.084 & -3.750 & -3.000 & -2.630 \\
\hline$Z(t)_{\text {ln_Density }}{ }_{4}$ & 0.442 & -3.750 & -3.000 & -2.630 \\
\hline$Z(t)_{\text {ln_Electricity }} 5$ & -1.921 & -3.750 & -3.000 & -2.630 \\
\hline$Z(t)_{\text {In Passenger }} 6$ & 0.161 & -3.750 & -3.000 & -2.630 \\
\hline$Z(t)_{\text {ln_Value }} 7$ & -2.626 & -3.750 & -3.000 & -2.630 \\
\hline$Z(t)_{\text {ln_Vehicle }}{ }^{8}$ & 2.923 & -3.750 & -3.000 & -2.630 \\
\hline
\end{tabular}

1 MacKinnon approximate $p$-value for $Z(t)_{\text {ln_Capita }}=0.9983 .{ }^{2}$ MacKinnon approximate $p$-value for $Z(t)_{\text {ln_Cargo }}=0.3395 .{ }^{3}$ MacKinnon approximate $p$-value for $Z(t)_{\text {ln_Container }}=0.0278 .{ }^{4}$ MacKinnon approximate $p$-value for $Z(t)_{\text {ln_Density }}=0.9830 .{ }^{5}$ MacKinnon approximate $p$-value for $Z(t)_{\text {ln_Electricity }}=0.3222 .{ }^{6}$ MacKinnon approximate $p$-value for $Z(t)_{l n_{-} \text {Passenger }}=0.9700 .{ }^{7}$ MacKinnon approximate $p$-value for $Z(t)_{l n_{-} \text {Value }}=0.0878$.

${ }^{8}$ MacKinnon approximate $p$-value for $Z(t)_{l n_{-} \text {Vehicle }}=1.0000$.

\section{Appendix D. Augmented Dickey-Fuller Test of Unit Root of Each Variable in Singapore}

Table A4. Augmented Dickey-Fuller Test of Unit Root of Each Variable in Singapore.

\begin{tabular}{|c|c|c|c|c|}
\hline Variables & Test Statistic & $1 \%$ Critical Value & $\begin{array}{c}\text { Augmented Dickey-Fuller } \\
5 \% \text { Critical Value }\end{array}$ & $10 \%$ Critical Value \\
\hline$Z(t)_{l n_{n} \text { Capita }} 1$ & -0.424 & -3.750 & -3.000 & -2.630 \\
\hline$Z(t)_{\text {ln_Cargo }}{ }^{2}$ & -0.811 & -3.750 & -3.000 & -2.630 \\
\hline$Z(t)_{\text {In Container }}{ }^{3}$ & -1.071 & -3.750 & -3.000 & -2.630 \\
\hline$Z(t)_{\text {ln Density }} 4$ & -0.461 & -3.750 & -3.000 & -2.630 \\
\hline$Z(t)_{\text {ln_Electricity }} 5$ & -1.408 & -3.750 & -3.000 & -2.630 \\
\hline$Z(t)_{\text {In_Passenger }} 6$ & -4.072 & -3.750 & -3.000 & -2.630 \\
\hline$Z(t)_{\text {ln_Value }} 7$ & -1.132 & -3.750 & -3.000 & -2.630 \\
\hline$Z(t)_{\text {ln_Vehicle }}{ }^{8}$ & -1.363 & -3.750 & -3.000 & -2.630 \\
\hline
\end{tabular}

1 MacKinnon approximate $p$-value for $Z(t)_{l n \_ \text {Capita }}=0.9061 .{ }^{2}$ MacKinnon approximate $p$-value for $Z(t)_{\text {ln_Cargo }_{0}}=0.8159 .{ }^{3}$ MacKinnon approximate $p$-value for $Z(t)_{\ln _{\text {Container }}}=0.7264 .{ }^{4}$ MacKinnon approximate $p$-value for $Z(t)_{\text {ln_Density }}=0.8994 .{ }^{5}$ MacKinnon approximate $p$-value for $Z(t)_{\text {ln_Electricity }}=0.5786 .{ }^{6}$ MacKinnon approximate $p$-value for $Z(t)_{l n \_ \text {Passenger }}=0.0011 .{ }^{7}$ MacKinnon approximate $p$-value for $Z(t)_{\text {ln_Value }}=0.7022$. ${ }^{8}$ MacKinnon approximate $p$-value for $Z(t)_{l_{\text {Vehicle }}}=0.5999$.

\section{References}

1. Haapio, A.; Viitaniemi, P. A critical review of building environmental assessment tools. Environ. Impact Assess. Rev. 2008, 28, 469-482. [CrossRef]

2. Crawley, D.; Aho, I. Building environmental assessment methods: Applications and development trends. Build. Res. Inf. 1999, 27, 300-308. [CrossRef]

3. Amiri, A.; Caddock, P.; Whitehead, M. Accounting for the greenhouse gas emissions of construction: A UK case study. Proc. Inst. Civ. Eng. Civ. Eng. 2013, 166, 82-88. [CrossRef]

4. Kamali, M.; Hewage, K. Life cycle performance of modular buildings: A critical review. Renew. Sustain. Energy Rev. 2016, 62, 1171-1183. [CrossRef]

5. Xu, Z.; Zayed, T.; Niu, Y. Comparative analysis of modular construction practices in mainland China, Hong Kong and Singapore. J. Clean. Prod. 2020, 245, 118861. [CrossRef]

6. Kamali, M.; Hewage, K.; Sadiq, R. Conventional versus modular construction methods: A comparative cradle-to-gate LCA for residential buildings. Energy Build. 2019, 204, 109479. [CrossRef] 
7. Quale, J.; Eckelman, M.J.; Williams, K.W.; Sloditskie, G.; Zimmerman, J.B. Construction matters: Comparing environmental impacts of building modular and conventional homes in the United States. J. Ind. Ecol. 2012, 16, 243-253. [CrossRef]

8. Lawson, M.; Ogden, R.; Goodier, C. Design in Modular Construction; CRC Press: Boca Raton, FL, USA, 2014.

9. Lee, K.B.; Kim, K.R.; Shin, D.W.; Cha, H.S. A proposal for optimizing unit modular system process to improve efficiency in off-site manufacture, transportation and on-site installation. Korean J. Constr. Eng. Manag. 2011, 12, 14-21. [CrossRef]

10. Staib, G.; Dörrhöfer, A.; Rosenthal, M. Components and Systems: Modular Construction-Design, Structure, New Technologies; Walter de Gruyter: Berlin, Germany, 2013.

11. Liu, S.; Qian, S. Evaluation of social life-cycle performance of buildings: Theoretical framework and impact assessment approach. J. Clean. Prod. 2019, 213, 792-807. [CrossRef]

12. Kamali, M.; Hewage, K. Development of performance criteria for sustainability evaluation of modular versus conventional construction methods. J. Clean. Prod. 2017, 42, 3592-3606. [CrossRef]

13. Hammad, A.W.; Akbarnezhad, A.; Wu, P.; Wang, X.; Haddad, A. Building information modelling-based framework to contrast conventional and modular construction methods through selected sustainability factors. J. Clean. Prod. 2019, 228, 1264-1281. [CrossRef]

14. Hong, J.; Shen, G.; Li, Z.; Zhang, B.; Zhang, W. Barriers to promoting prefabricated construction in China: A cost-benefit analysis. J. Clean. Prod. 2018, 172, 649-660. [CrossRef]

15. Miller, W.F. Energy and Environmental Benefits of Structural Insulated Panels for Residential Construction in Australia; Metecno Pty Ltd.: Brisbane, Australia, 2010.

16. Pan, W.; Sidwell, R. Demystifying the cost barriers to offsite construction in the UK. Constr. Manag. Econ. 2011, 29, 1081-1099. [CrossRef]

17. Salama, T.; Salah, A.; Moselhi, O.; Al-Hussein, M. Near optimum selection of module configuration for efficient modular construction. Autom. Constr. 2017, 83, 316-329. [CrossRef]

18. Liu, C.; Chen, J. Study on Influence of Prefabricated Rate on the Cost of Prefabricated Building. In Proceedings of the ICCREM 2019: Innovative Construction Project Management and Construction Industrialization, Banff, AB, Canada, 21-24 May 2019; pp. 554-561.

19. Luo, S.; Li, S. Quantitative analysis of the influence of prefabrication on construction cost. Constr. Econ. 2016, 37, 48-53.

20. Zhang, W.; Lee, M.W.; Jaillon, L.; Poon, C.S. The hindrance to using prefabrication in Hong Kong's building industry. J. Clean. Prod. 2018, 204, 70-81. [CrossRef]

21. Lu, W.; Yuan, H. Investigating waste reduction potential in the upstream processes of offshore prefabrication construction. Renew. Sustain. Energy Rev. 2013, 28, 804-811. [CrossRef]

22. Liew, K.H. Manifestos for Sustainable Development: Sustainable Modular Steel-Precast Concrete Building Construction System for Dwellings in Singapore. In Sustainable Development Research in the Asia-Pacific Region; Leal Filho, W., Rogers, J., Iyer-Raniga, U., Eds.; World Sustainability Series; Springer: Cham, Switzerland, 2018; pp. 477-492.

23. Cao, X.; Li, X.; Zhu, Y.; Zhang, Z. A comparative study of environmental performance between prefabricated and traditional residential buildings in China. J. Clean. Prod. 2015, 109, 131-143. [CrossRef]

24. Dong, Y.; Jaillon, L.; Chu, P.; Poon, C.S. Comparing carbon emissions of precast and cast-in-situ construction methods-A case study of high-rise private building. Constr. Build. Mater. 2015, 99, 39-53. [CrossRef]

25. Li, Z.; Shen, G.; Alshawi, M. Measuring the impact of prefabrication on construction waste reduction: An empirical study in China. Resour. Conserv. Recycl. 2014, 91, 27-39. [CrossRef]

26. Tavares, V.; Lacerda, N.; Freire, F. Embodied energy and greenhouse gas emissions analysis of a prefabricated modular house: The "Moby" case study. J. Clean. Prod. 2019, 212, 1044-1053. [CrossRef]

27. Jaillon, L.; Poon, C.S. Sustainable construction aspects of using prefabrication in dense urban environment: A Hong Kong case study. Constr. Manag. Econ. 2008, 26, 953-966. [CrossRef]

28. Rahman, M.; Sobuz, H.R. Comparative study of IPS \& PPVC precast system-A case study of public housing buildings project in Singapore. In Proceedings of the 4th International Conference on Civil Engineering for Sustainable Development (ICCESD 2018), KUET, Khulna, Bangladesh, 9-11 February 2018; Volume 4149, pp. 1-12.

29. Zhao, P.; Feng, Y.; Jin, J.; Han, B.; Bi, X.; Zhu, T.; Zhang, X. Characteristics and control indicators of fugitive dust from building construction sites. Acta Sci. Circumstantiae 2009, 29, 1618-1623.

30. Teng, Y.; Li, K.; Pan, W.; Ng, T. Reducing building life cycle carbon emissions through prefabrication: Evidence from and gaps in empirical studies. Build. Environ. 2018, 132, 125-136. [CrossRef]

31. Kawecki, L.R. Environmental Performance of Modular Fabrication: Calculating the Carbon Footprint of Energy Used in the Construction of a Modular Home. Ph.D. Thesis, Arizona State University, Tempe, AZ, USA, 2010.

32. Pons, O.; Wadel, G. Environmental impacts of prefabricated school buildings in Catalonia. Habitat Int. 2011, 35, 553-563. [CrossRef]

33. Al-Hussein, M.; Manrique, J.D.; Mah, D. North Ridge $\mathrm{CO}_{2}$ Analysis Report: Comparison between Modular and On-Site Construction; University of Alberta: Edmonton, AB, Canada, 2009.

34. Dodoo, A.; Gustavsson, L.; Sathre, R. Lifecycle carbon implications of conventional and low-energy multi-storey timber building systems. Energy Build. 2014, 82, 194-210. [CrossRef] 
35. Pan, W.; Li, K.; Teng, Y. Briefing: Life-cycle carbon assessment of prefabricated buildings: Challenges and solutions. Proc. Inst. Civ. Eng. Eng. Sustain. 2018, 172, 3-8. [CrossRef]

36. Xing, J.; Wang, S.; Chatani, S.; Zhang, C.; Wei, W.; Hao, J.; Klimont, Z.; Cofala, J.; Amann, M. Projections of air pollutant emissions and its impacts on regional air quality in China in 2020. Atmos. Chem. Phys. 2011, 11, 3119-3136. [CrossRef]

37. Ni, T.; Han, B.; Bai, Z. Source apportionment of PM10 in four cities of northeastern China. Aerosol Air Qual. Res. 2012, 12, 571-582. [CrossRef]

38. Sik, K.Y.; Choi, W.; Joong, O.K. A Study of the amount of fugitive dust generated from new harbor construction site and the prediction of effect using Aermod. J. Environ. Health Sci. 2009, 35, 304-314.

39. Du, Y.; Ren, H.; Cai, W.; Qin, B.; Ma, X. Effect of Construction Dust on Urban PM 2.5 Emission Characteristics: A Case Study of the Main Urban Area of Chongqing, China. Nature Environ. Pollut. Technol. 2016, 15, 833-840.

40. Chang, C.; Chang, Y.; Lin, W.; Wu, M. Fugitive dust emission source profiles and assessment of selected control strategies for particulate matter at gravel processing sites in Taiwan. J. Air Waste Manag. Assoc. 2010, 60, 1262-1268. [CrossRef]

41. Celine, J.L. The Evolution of the Use of Prefabrication Techniques in Hong Kong Construction Industry. Ph.D. Thesis, Hong Kong Polytechnic University, Hong Kong, China, 2009.

42. Lawson, M.; Ogden, R.; Bergin, R. Application of modular construction in high-rise buildings. J. Archit. Eng. 2012, 18, 148-154. [CrossRef]

43. Velasco, E.; Roth, M. Review of Singapore's air quality and greenhouse gas emissions: Current situation and opportunities. J. Air Waste Manag. Assoc. 2012, 62, 625-641. [CrossRef]

44. Zhan, S. Research on Changing Trend and Influencing Factors of Conventional Air Pollutants in Guangdong-Hongkong-Macao Greater Bay Area. Ph.D. Thesis, University of Chinese Academy of Sciences, Guangzhou, China, 2018.

45. Zhang, X.; Gong, Z. Spatiotemporal characteristics of urban air quality in China and geographic detection of their determinants. J. Geogr. Sci. 2018, 28, 563-578. [CrossRef]

46. World Health Organization (WHO). Ambient (Outdoor) Air Pollution. 2021. Available online: https://www.who.int/newsroom/fact-sheets/detail/ambient-(outdoor)-air-quality-and-health (accessed on 22 September 2021).

47. Mak, Y.W. Prefabrication and Industrialisation of Housing in Hong Kong. Master's Thesis, Hong Kong Polytechnic University, Hong Kong, China, 1998.

48. Cen, Y.; Deng, W.M. The development of prefabricated buildings in Hong Kong. Hous. Ind. 2017, 12, 15-21.

49. Ting, S.K.; Jin, H.F. Prefabrication in the Singapore Construction Industry. In Proceedings of the 17th IAARC/CIB/IEEE/IFAC/IFR International Symposium on Automation and Robotics in Construction: 17th ISARC 2000, Taipei, Taiwan, 18-20 September 2000; Volume 66, pp. 1-6.

50. Building and Construction Authority. Annex C Buildable Score Appraisal System. 2017. Available online: https://www.bca.gov. sg/Publications/BuildabilitySeries/others/rscp_anxc.PDF (accessed on 25 September 2017).

51. Building and Construction Authority. Code of Practice on Buildable Design. 2000. Available online: https://www1.bca.gov. sg/docs / default-source/docs-corp-news-and-publications/publications/for-industry/buildability-series/copbddec00.pdf (accessed on 30 December 2021).

52. Park, M.; Ingawale-Verma, Y.; Kim, W.; Ham, Y. Construction policymaking: With an example of Singaporean government's policy to diffuse prefabrication to private sector. KSCE J. Civ. Eng. 2011, 15, 771-779. [CrossRef]

53. Gao, Y. Research on the development of prefabricated Buildings in Singapore. Hous. Ind. 2016, 6, 45-49.

54. Ellis, P. Uncertainty in the Hong Kong Special Administrative Region. (HKSAR). Bus. Horiz. 1997, 40, 59-64. [CrossRef]

55. Aye, L.; Ngo, T.; Crawford, R.H.; Gammampila, R.; Mendis, P. Life cycle greenhouse gas emissions and energy analysis of prefabricated reusable building modules. Energy Build. 2012, 47, 159-168. [CrossRef]

56. Mao, C.; Shen, Q.; Shen, L.; Tang, L. Comparative study of greenhouse gas emissions between off-site prefabrication and conventional construction methods: Two case studies of residential projects. Energy Build. 2013, 66, 165-176. [CrossRef]

57. Cole, M.A.; Neumayer, E. Examining the Impact of Demographic Factors on Air Pollution. Popul. Environ. 2004, 26, 5-21. [CrossRef]

58. Qiu, G.; Song, R.; He, S. The aggravation of urban air quality deterioration due to urbanization, transportation and economic development-Panel models with marginal effect analyses across China. Sci. Total Environ. 2019, 651, 1114-1125. [CrossRef]

59. Lonati, G.; Cernuschi, S.; Sidi, S. Air quality impact assessment of at-berth ship emissions: Case-study for the project of a new freight port. Sci. Total Environ. 2010, 409, 192-200. [CrossRef] [PubMed]

60. Zhang, K.; Batterman, S. Air pollution and health risks due to vehicle traffic. Sci. Total Environ. 2013, 450, 307-316. [CrossRef]

61. Chan, A.P.C. Modelling building durations in Hong Kong. Constr. Manag. Econ. 1999, 17, 189-196. [CrossRef]

62. South China Moring Post. Singapore is Embracing 'Lego Style' Prefabricated Construction Method for Residential Housing. 2019. Available online: https://www.scmp.com/property/international/article/3017734/singapore-embracing-lego-styleprefabricated-construction (accessed on 8 July 2019).

63. Buildings Department. Joint Practice Note No. 1. 2001. Available online: https://www.bd.gov.hk/doc/en/resources/codes-andreferences/practice-notes-and-circular-letters/joint/JPN01.pdf (accessed on 30 December 2021).

64. Buildings Department. Joint Practice Note No. 2. 2002. Available online: https://www.bd.gov.hk/doc/en/resources/codes-andreferences/practice-notes-and-circular-letters/joint/JPN02.pdf (accessed on 30 December 2021). 
65. Buildings Department. Code of Practice for Precast Concrete Construction. 2003. Available online: https://www.bd.gov.hk/doc/ en/resources/codes-and-references / code-and-design-manuals/OldVersions/CoP_CPPCC_ov.zip (accessed on 30 December 2021).

66. Buildings Department. Code of Practice for Precast Concrete Construction. 2016. Available online: https://www.bd.gov.hk/doc/ en/resources / codes-and-references / code-and-design-manuals/cppcc2016e.pdf (accessed on 30 December 2021).

67. Building and Construction Authority. Code of Practice on Buildable Design. 2002. Available online: https://www1.bca.gov.sg/ docs/default-source/docs-corp-news-and-publications / publications/for-industry/buildability-series/codeofpractice.pdf (accessed on 30 December 2021).

68. Building and Construction Authority. Code of Practice on Buildable Design. 2004. Available online: https://www1.bca.gov. sg/docs/default-source/docs-corp-news-and-publications/publications/for-industry/buildability-series/copbdjan04.pdf (accessed on 30 December 2021).

69. Building and Construction Authority. Code of Practice on Buildable Design. 2005. Available online: https://www1.bca.gov. sg/docs/default-source/docs-corp-news-and-publications / publications/for-industry/buildability-series/copbdsep05.pdf (accessed on 30 December 2021).

70. Building and Construction Authority. Code of Practice on Buildable Design. 2011. Available online: https://www1.bca.gov.sg/ docs/default-source/docs-corp-news-and-publications / publications / for-industry/buildability-series/copbdapr2011.pdf (accessed on 30 December 2021).

71. Building and Construction Authority. Code of Practice on Buildable Design. 2013. Available online: https://www1.bca.gov.sg/ docs/default-source/docs-corp-news-and-publications / publications / for-industry / buildability-series/copbdsep2013.pdf (accessed on 30 December 2021).

72. Building and Construction Authority. Code of Practice on Buildable Design. 2014. Available online: https://www1.bca.gov.sg/ docs / default-source/docs-corp-news-and-publications / publications / for-industry/buildability-series/copbdnov2014.pdf (accessed on 30 December 2021).

73. Building and Construction Authority. Code of Practice on Buildable Design. 2015. Available online: https://www1.bca.gov.sg/ docs/default-source/docs-corp-news-and-publications/publications/for-industry/buildability-series/copbdnov2015.pdf (accessed on 30 December 2021).

74. Building and Construction Authority. Code of Practice on Buildable Design. 2017. Available online: https://www1.bca.gov.sg/ docs / default-source/docs-corp-buildsg/productivity/cop2017.pdf?sfvrsn=4a5c7b434 (accessed on 30 December 2021). 